\title{
Income Support, (Un-)Employment and Well-Being
}

Clemens Hetschko

Ronnie Schöb

Tobias Wolf

School of Business \& Economics

Discussion Paper

Economics

$2016 / 15$ 


\title{
Income Support, (Un-)Employment and Well-Being
}

\author{
Clemens Hetschko \\ Freie Universität Berlin, CESifo \\ Ronnie Schöb \\ Freie Universität Berlin, ifo Dresden, CESifo \\ Tobias Wolf* \\ Freie Universität Berlin
}

July 2016

\begin{abstract}
Using specific panel data of German welfare benefit recipients, we investigate the nonpecuniary life satisfaction effects of in-work benefits. Our empirical strategy combines difference-in-difference designs with synthetic control groups to analyze transitions of workers between unemployment, regular employment and employment accompanied by welfare receipt. Working makes people generally better off than being unemployed, but employed welfare recipients do not reach the life satisfaction level of regular employees. This implies that welfare receipt entails non-compliance with the norm to make one's own living. Our findings allow us to draw cautious conclusions on employment subsidies paid as welfare benefits.
\end{abstract}

JEL Classification Codes: I31, I38, J60, J68

Keywords: life satisfaction, subsidized employment, unemployment, income support, in-work benefits, social norms

\footnotetext{
${ }^{*}$ Corresponding author. Contact: Freie Universität Berlin, School of Business and Economics, Boltzmannstraße 20, D-14195 Berlin, Germany; E-mail: tobias.wolf@fu-berlin.de

Acknowledgements. We are grateful for very valuable comments made by Katja Görlitz, Andreas Knabe, Adrian Chadi and Rainer Winkelmann as well as by participants of seminars at the universities of Umeå, Basel and Salzburg (2016), of the $30^{\text {th }}$ annual meeting of the European Society of Population Economics (Berlin, 2016) and of the 2016 Stirling PhD Conference in Behavioural Science. Financial support by the DFG (project no, SCHO $1270 / 3-1)$ is gratefully acknowledged.
} 
Pecunia non olet

Vespasian

\section{Introduction}

Income increases people's consumption opportunities, irrespective of its source, and thus raises individual welfare. In this paper, we question this generally held view in economics and argue that the source of income does matter for individual well-being, at least for those employed workers who receive supplementary income support, i.e. in-work benefits. They may suffer from being dependent on public income support rather than being able to make their own living.

One main aim of in-work benefits is to help the unemployed to overcome joblessness. Previous insights on the well-being effects of unemployment shed light on the potential benefits of such a policy, but likewise point to its possible drawback. Being jobless reduces life satisfaction far beyond the misery caused by the income loss (see e.g. Winkelmann and Winkelmann 1998, Blanchflower and Oswald 2004, Knabe and Rätzel 2011) as it worsens perceived social status, causes people to violate the social norm to work and leads to a deterioration in self-esteem, or identity utility (cf. Schöb 2013). Thus, even a very generous passive labor market policy that compensated unemployed workers fully for the income loss would fail to restore their overall well-being.

Active labor market policy (ALMP) aimed at fostering reemployment therefore seems, at first glance, to be a more promising tool to alleviate unemployment-induced well-being losses. Employment subsidization schemes, such as the US 'Earned Income Tax Credit', the French 'La prime pour l'emploi', the British 'Working Tax Credit' and the German 'Ergänzendes Arbeitslosengeld II' (supplementary unemployment benefits II, UB II in the following) are prominent examples. They increase the income of low-paid workers to raise their labor supply while keeping firms' labor costs low and labor demand high (Saez 2002, Brewer et al. 2006, Chetty, Friedman and Saez 2013). Creating additional jobs for unemployed workers in this way, inter alia, helps them to restore compliance with the norm to work and should thus raise their life satisfaction. It is an unsettled question, however, whether such policy tools allow subsidized workers to fully recover their original level of life satisfaction. This will only be the case if the subsidy does not affect subjective well-being beyond its income effect. When workers' identity not only depends on being employed, but also on adhering to what we term the non-dependency norm, i.e. the norm of making a living by one's own efforts (Elster 1989), an employment subsidy shaped as income support will not suffice to completely remove the misery of the unemployed. Workers who receive part of their salary in the form of public income support 
may realize that they live off public assistance instead of making their own living. As a result, they may be less satisfied with their lives than non-subsidized (in the following also 'regularly') employed workers.

In this study, we assess the role of the non-dependency norm for employees' well-being by analyzing the well-being effects of subsidized employment in the form of in-work benefits compared to unemployment and regular employment. We examine the well-being of working UB II recipients in Germany, using data of the Panel Arbeitsmarkt und soziale Sicherung ('Panel Study Labour Market and Social Security', in the following: PASS). The panel structure of PASS and its special focus on welfare recipients allows us to follow workers out of subsidized employment and into it, entering or coming from either regular employment or unemployment, and to observe the within-person changes in life satisfaction accompanying these transitions. Our identification strategy addresses selection due to both time-invariant unobservable and time-variant observable characteristics by utilizing difference-in-differences designs and constructing synthetic control groups. Multiple regression analyses enable us to disentangle the monetary effect of transitions into or out of the receipt of in-work benefits from the respective non-monetary effect and to control for potentially confounding factors.

We find that people become better off when they leave unemployment and start to work while continuing to receive welfare and that this cannot be solely explained by the associated rise in available income. Employed people who leave income support and become regularly employed also experience an increase in life satisfaction, even when controlling for income changes. As these people enjoy all the genuine benefits of employment before and after the change, such as adhering to the work norm, this second finding points to a negative impact of receiving income support. This result is in line with the hypothesis that in-work benefits prevent the beneficiaries from complying with the non-dependency norm.

We proceed as follows: Section 2 summarizes previous findings on the well-being effects of unemployment and welfare dependency to develop hypotheses for our empirical analyses. Data and sampling are described in Section 3. Our empirical identification strategy is elaborated in Section 4. Section 5 presents our main results and the robustness checks conducted. Section 6 concludes.

\section{Previous literature, hypotheses and contribution}

Losing work influences subjective well-being in different ways. It has a strong impact on life satisfaction, but hardly any impact on affective measures of well-being. Thus, unemployment affects the cognitive evaluation of one's whole life, such as future uncertainty or the perception 
of one's self, rather than the frequency of positive and negative emotions experienced over the course of the day (Knabe et al. 2010). Violating the social norm to work partly explains the harmful impact of losing work on the cognitive component of well-being. The jobless suffer more in regions with relatively low unemployment rates despite the fact that they have better reemployment prospects there. It seems that the social norm to work is all the stronger, the greater the number of people in the immediate vicinity who are able to comply (Clark 2003, Shields and Wheatley Price 2005, Powdthavee 2007, Shields, Wheatley Price and Wooden 2009). Similarly, job seekers suffer, in particular, in regions where higher shares of voters support cuts in unemployment benefits (Stutzer and Lalive 2004). Retirement increases unemployed workers' life satisfaction, presumably because it allows them to leave the social category 'working age', whose norm to work they violate, and enter the social category 'retirement age', which does not prescribe being employed (Hetschko, Knabe and Schöb 2014). In line with these findings, we formulate

\section{Hypothesis 1: LS(Unemployed,$\bullet)<L S($ Subsidized employed,$\bullet)$,}

where $L S$ denotes life satisfaction. Primarily because of the strong role of the social norm to work, we expect Hypothesis 1, ceteris paribus, to hold even when the difference in income between the two labor market states is controlled for. ${ }^{1}$

Besides violation of the work norm, non-compliance with the norm to make a living by one's own efforts could also explain why people suffer a great deal from unemployment (Chadi 2014). Here, a negative impact on well-being may originate from two kinds of welfare stigma (Moffitt 1983, Stuber and Schlesinger 2006, Kassenboehmer and Haisken-DeNew 2009): a negative self-perception as a dependent individual (identity stigma) and negative treatment from others (treatment stigma, see Besley and Coate 1992). Identity stigma and treatment stigma could explain why many people do not apply for welfare although they are eligible (Riphahn 2001, Whelan 2010, Bruckmeier et al. 2013). Non-take-up behavior, however, might also originate from the individual cost of filing for welfare or lacking knowledge about one's eligibility for welfare. In these cases, being dependent on welfare itself does not need to reduce utility. It is therefore worth analyzing life satisfaction in order to directly identify the effect of welfare receipt on workers' well-being. This is how our contribution relates to the non-take up literature.

\footnotetext{
${ }^{1}$ In line with this notion, analyses of well-being effects of targeted ALMP programs suggest that the detrimental effects of being unemployed on well-being can be partly overcome by participating in such progams (Korpi 1997, Krug 2009, Bonin and Rinne 2014).
} 
According to Chadi $(2012,2014)$ life satisfaction and proxies of violating the nondependency norm, such as the receipt of diverse transfers, are negatively correlated. This also applies to those employed male workers who receive income support at the individual level. We therefore conjecture that becoming regularly employed restores job seekers' adherence to both the work norm and the non-dependency norm. In contrast, becoming reemployed thanks to in-work benefits conditional on household neediness (e.g. due to low wage income) ensures adherence to the work norm only. Employed workers subsidized in this way are still welfaredependent, which could continue to interfere with the individual well-being level due to the stigma of the deviation from the non-dependency norm. Assuming that violating the nondependency norm, ceteris paribus, affects subsidized employees' well-being negatively, we formulate

Hypothesis 2: LS(Subsidized employed, $\bullet)<L S($ Regularly employed, $\bullet)$.

In order to test these two hypotheses, we provide the first specific inquiry into the well-being effects of in-work benefits. These benefits have to date mostly been analyzed regarding their impact on the decision to work, hours of work and the well-being consequences of very specific target groups such as single mothers (Blundell 2000, Blundell and Hoynes 2004, Dorsett and Oswald 2014, Van der Linden 2016). This study extends the existing branches of literature on (un-)employment and well-being as well as those on the effects of welfare receipt in several ways. Employing difference-in-differences designs with synthetic control groups, we can approach the true life satisfaction effects of receiving in-work benefits much closer than Chadi's (2012, 2014) overviews of empirical relationships of transfer receipt and well-being. The PASS dataset's focus on unemployment benefit II recipients allows us to take into account many observable characteristics that could simultaneously explain the selection into welfare receipt and differences in life satisfaction, but which have been neglected so far (e.g. amount of savings). The panel structure of PASS moreover provides us with the opportunity to investigate potential differences between transitions into and out of labor market states. Finally, the data enable us to shed light on potential sources of stigma in order to explain why welfare receipt reduces employees' life satisfaction. 


\section{Institutional background, data and samples}

The Sozialgesetzbuch II (Social Code II) regulates income support in Germany. Welfare benefits are paid to single persons or joint households ("Bedarfsgemeinschaft") ${ }^{2}$ that are unable to generate a well-defined socio-economic subsistence level of self-earned income and cannot rely on wealth. ${ }^{3} \mathrm{Up}$ to this level, 'unemployment benefits II' (Arbeitslosengeld II, UB II) supplements the household's income. ${ }^{4}$ Employees who live in households with low income are thus eligible to receive supplementary UB II. As long as the monthly gross labor income is less than 100 euros, UB II entitlement is not reduced at all. Each euro of additionally earned labor income reduces UB II by 80 cents up to a threshold of 1,000 euros per month. From 1,000 to 1,200 euros, UB II is reduced by $90 \%$ (1,500 euros if the worker has dependent children). Beyond that, labor income replaces UB II completely. As a result, people can receive welfare benefits even though their total net income (welfare benefits plus earnings) exceeds the socioeconomic subsistence level. This is intended to encourage workers to accept low-paid jobs.

We make use of PASS data covering about 15,000 individuals living in 10,000 households in Germany who have been surveyed annually since 2006. The panel structure enables us to exploit within-person variation. The survey consists of two parts ('dual sampling'). One sample represents the general population, whereas the other sample is drawn from register data and includes only households receiving UB II. As a result, PASS surveys considerably more inwork benefit recipients per year than comparable household surveys. The two parts of the survey do not vary regarding the information included. The data cover subjective well-being, employment biographies and other relevant characteristics. Furthermore, PASS contains many UB II specific questions (see Trappmann et al. 2010, 2013). We utilize all the waves starting from the second wave onwards $(2007 / 08,2008 / 09,2010,2011,2012,2013,2014)$. Due to fundamental changes in the questionnaire design we do not make use of the first PASS wave

\footnotetext{
2 Persons can qualify for such a joint entitlement in the cases of cohabitation, marriage and dependent children.

3 The level of normal requirements changes on a yearly basis and is 404 euros monthly (January 2016) for the first adult in household and 364 euros for her spouse. Children younger than 6 years give rise to an entitlement of 237 euros, 6-13 year old children 270 euros, 14-17 year old children 306 euros, and 18-25 year old dependent adults 324 euros. Accommodation and heating are paid separately and are set at the city/county level.

${ }^{4}$ When workers become unemployed, they receive unemployment insurance benefits (Arbeitslosengeld I, UB I in the following), which amounts to $60 \%$ of the former net labor income (67\% in exceptional cases). As long as UB I is not as high as the socio-economic subsistence level, workers can receive supplementary UB II. After a certain period of time, the entitlement for UB I expires (between 6 and 24 months, depending on the age of the recipient and the time he has contributed to the insurance). Henceforth, unemployed workers are only eligible for meanstested UB II.
} 
(2006/07). In doing so, we also substantially reduce the problem that people tend to report higher life satisfaction when surveyed for the first time (e.g. Frijters und Beatton 2012). ${ }^{5}$

We distinguish three distinct individual labor market states: regularly employed, subsidized employed and unemployed. For the purpose of our analysis, we define a person as employed if she reports any employment spell (including self-employment) at the time of the interview. Besides this information, we condition being employed on a working time from 15 hours to 80 hours a week and not being registered as unemployed. Employees who do not receive income support are considered regularly employed, while employees who do live in a UB II receiving household are considered subsidized employed. Unemployed workers are not employed, are registered as unemployed and do not report any employment spell at the time of the interview (not even a marginal employment in German "mini-job"). We restrict our samples to persons of working age (18-65 years) and explicitly exclude pupils, students, workers on parental leave, (early-) retirees, public servants and participants of selective ALMPs (the German 'One-EuroJobs', retraining, etc.). Given these restrictions, the PASS waves we use include 29,957 observations of regularly employed workers, 3,435 observations of employees receiving income support and 21,383 observations of unemployed people.

Subjective well-being is measured using a general question on people's life satisfaction, 'In general, how satisfied are you currently with your life on the whole?', which respondents answer on an eleven-point scale from ' $0=$ very dissatisfied' to ' $10=$ very satisfied'. In addition, we make use of data on the disposable equalized monthly household income, which approximates individual consumption opportunities by accounting for the number of household members and economies of scale in housing. ${ }^{6}$ As proxies for household wealth, we introduce indicators for the stock of savings (from savings accounts, shares, building society deposits, and life insurances, but not real estate). Socio-demographic characteristics are gender, age, number of adults and children in household, marital status, migration background, years of schooling and living in the former East or West Germany. Data on social relations outside the household are included as well. Current health status is represented by being registered as disabled or not, filing for disability or not (as current disability shock), the number of visits to a doctor within the last three months and the report of zero/one or more hospital stays within the last twelve months.

\footnotetext{
${ }^{5}$ Along these lines, we also checked whether controls for time-in-panel and sample origin (the two initial samples, refreshments) affect our results, but this does is not the case.

${ }^{6}$ Following the OECD equivalence scale, the disposable household income is divided by a weighted number of the persons living in the same household. While the first person gets a weight of 1 , any additional person older than 14 years gets a weight of 0.5 , children up to the age of 14 years get a weight of 0.3 .
} 
For employed individuals we include information about job characteristics, such as gross labor earnings, actual weekly working hours, job type (blue collar/white collar/selfemployed) and the duration of the current employment spell (tenure). Work strain is considered in a novel way by merging a rich work strain index ('Arbeitsbelastungsindex', see Kroll 2011) with our data. The scale is generated from 39 items of a job questionnaire and aggregates ergonomic burden, psychological strain, social strain, environmental burden and temporal burden of the current occupation. Based on the International Standard Classification of Occupations (ISCO-88), we assign the resulting work strain value (' $1=$ lowest strain level' to ' $10=$ highest strain level') to all employees in the sample. ${ }^{7}$ This detailed information allows us to capture occupation-specific job characteristics on a very detailed level. For instance, the strain from being a waiter or barkeeper (ISCO-88 code 5123) is ' 9 ', whereas the work strain for a restaurant manager (ISCO-88 code 1315) is ' 8 '. By doing so, we also capture occupationspecific job insecurity and job-related health risks. Finally, we make use of data on the number of workers' recent personal contacts to the 'Jobcenter' in charge. ${ }^{8}$

\section{Empirical strategy}

Ideally, we would rely on purely exogenous variation in labor market status to identify life satisfaction effects of subsidized employment compared to unemployment and regular employment. However, this is not feasible based on the data at hand, but we can address endogeneity in three steps. A combined procedure tackles potential selection-into-treatment issues (here: selection into transitions between labor market states) originating from unobserved heterogeneity by a difference-in-differences design (first step, Subsection 4.1) and observable heterogeneity by a matching technique (second step, Subsection 4.2). In a third step (Subsection 4.3), DiD estimations that control for confounding variables disentangle the genuine effects of being subsidized (e.g. transfer income as potential source of stigma) from the genuine effects of the reasons for being subsidized employed (e.g. the well-being effect of the parallel income change). Our identifying assumption is, hence, that our estimates of effects of subsidized employment compared to regular employment and unemployment are unbiased by time-variant factors that are not taken into account by matching or the DiD estimations.

\footnotetext{
$781 \%$ of merged work strain scores are ISCO-88 4-digit level, for $16 \%$ of occupations we have information on a 3 -digit level and 3\% of our work strain information were merged on a 2-digit ISCO-88 code level.

8 'Jobcenter' is the official German (!) term. This local merger of social security office and employment agency administers UB II for both employed and unemployed people. In addition, it is supposed to help and incentivize them to overcome welfare dependency.
} 


\subsection{Difference-in-differences design}

We conduct four separate difference-in-differences approaches (DiD). Each DiD approach examines within-worker variations in life satisfaction $(L S)$ accompanying the transitions from subsidized employment to either unemployment or regular employment and vice versa. By doing so, we rule out that time-invariant unobserved heterogeneity, which simultaneously affects people's labor market status and well-being, confounds the genuine life satisfaction effects of the labor market states. In addition, this strategy allows us to examine whether the respective direction of the transition matters by analyzing all the transitions separately instead of applying a framework that combines all the transitions in one approach, such as an individual fixed effects estimation. Hence, it is tested whether, for instance, transitions from unemployment into subsidized employment and out of subsidized employment into unemployment yield qualitatively and quantitatively corresponding well-being changes or not. Finally, considering transitions separately allows us to assign transition-specific synthetic control groups to the respective treatment groups (see the following subsection). In doing so, we take into account that, for instance, regular employees and unemployed workers who become subsidized employees differ from each other in many respects.

We group our DiD approaches according to the hypotheses to be examined (see Section 2). To begin with, we focus on 'treated' individuals switching either from unemployment to subsidized employment (Test I.1) or vice versa (Test I.2). Subsequently, we track life satisfaction changes of regularly employed individuals who change to subsidized employment (Test II.1) and subsidized employed persons switching to regular employment (Test II.2). The transitions always take place between two PASS interviews, which generally encompass a period of approximately one year. The respective control groups always stay in the initial labor market status. This is necessary to disentangle the treatment effects in $L S$ from counterfactual changes in $L S$ (e.g. time trends). The DiD is thus the difference in the changes in $L S$ from one PASS interview to the next between the respective treatment and control groups. Figure 1 summarizes the four $\mathrm{DiD}$ approaches and assigns the numbers of observations to each treatment and control group. 
Figure 1: The different DiD designs

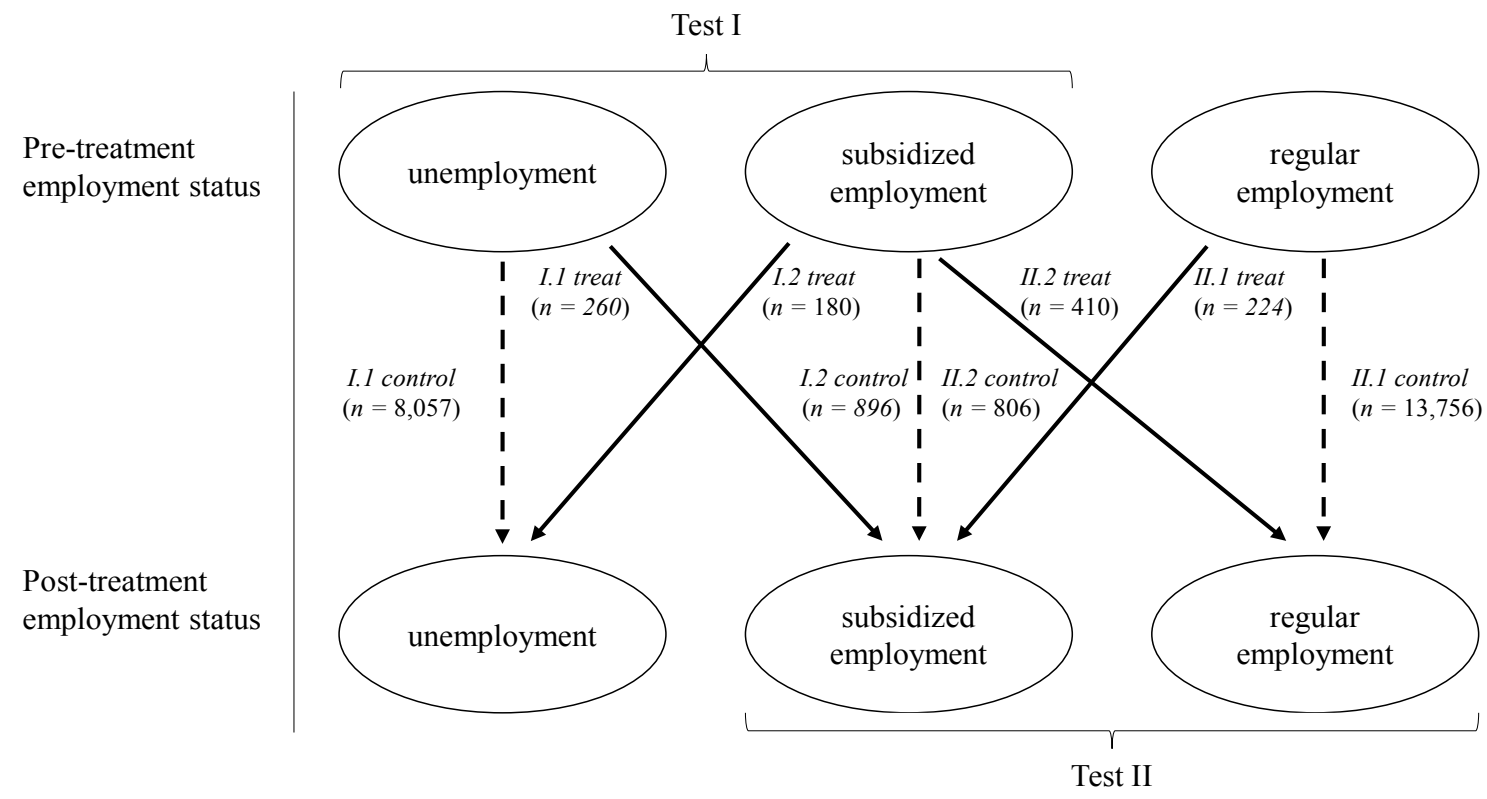

Note. The figure depicts the different treatment and control groups and their respective numbers of observations. For the size of control group I.2 and II.2, (remaining subsidized employed) this number differs slightly since different control variables are included and cause different missing values.

\subsection{Matching}

The probability of switching from one labor market status to another between two PASS interviews may vary with observable characteristics such as age, marital status, income or stock of savings. If these characteristics influence the change in well-being by the time the next PASS interview takes place, they will confound the true well-being effects between the respective treatment groups and the corresponding control groups. We therefore aim to equalize the propensities to be treated between those groups separately for each test.

Considering transitions separately in the $\mathrm{DiD}$ design is a first step to making the respective treatment and control groups more comparable since they each start from the same labor market status. To further increase similarity, we exploit the richness of the PASS dataset and take an extensive number of characteristics into account in order to reweight the observations of the transition-specific control groups such that, ideally, they face the same ex ante propensity to transition as the treatment group. Meeting UB II eligibility criteria affects this propensity. We therefore condition on measures of income, savings, marital status and number of person in a household (adults and children). The propensities to switch between subsidized employment, unemployment and regular employment may also depend on gender, age, educational attainment, migration background, social contacts, region (East vs. West Germany) and health status, which are thus considered as well. For people starting the transition from either 
subsidized or regular employment, we can also account for job characteristics that may differ regarding the probability of prospective transitions (differences in earnings, work strain, working hours and tenure, blue-collar, white-collar, or self-employment).

The reweighting technique entropy balancing (EB) is used to generate individual weights for all observations of the control groups such that the statistical moments of the given sets of observable characteristics, and thus ideally the propensity to be treated, equalize between the treatment and the control group (cf. Hainmueller 2012). For this purpose, a loss function minimizes the entropy distance of control group individuals' base weights ${ }^{9}$ and EB weights upon the condition that the set of control group covariate moments are as similar as possible to the treatment group moments. ${ }^{10}$ In contrast to propensity score based matching methods, this condition guarantees high matching quality as the covariate distributions of the treatment and control groups will definitely equalize. EB thus also obviates the complex and somewhat arbitrary process of choosing 'the right' covariates in order to achieve balanced covariate distributions (see, e.g., Caliendo and Kopeinig 2008 on the 'statistical issue' of variable choice). In addition, EB does not need to rely on the assumptions of propensity score estimations. ${ }^{11}$ Using the alternative propensity score reweighting technique does not qualitatively affect our results though, i.e. our findings are not sensitive to the weighting procedure applied. ${ }^{12}$

Tables A1-A4 in the Appendix describe the $L S$ as well as conditioning variables of the treatment and control groups of each DiD approach before and after reweighting. ${ }^{13}$ These tables document that, before reweighting, the treatment and control groups differ in many respects. EB eliminates the observed differences between treatment and control groups. Except for test I.2, balancing also reduces the gaps in pre-treatment $L S$ between treatment and control groups, although $L S$ is not included in the sets of conditioning variables.

\subsection{Regression analyses}

As mentioned above, changes in income or size of the joint household trigger switches out of and into subsidized employment. If these changes themselves affect well-being, they will confound the genuine effects of switching labor market states. To eliminate such sources of bias, we conduct multiple regression analyses based on the EB-reweighted control groups. The

\footnotetext{
${ }^{9}$ Each observation is given the same base weight.

10 We have implemented EB using the Stata package ebalance written by Hainmueller and Xu (2013).

11 These reasons explain why EB is increasingly popular. For previous applications see, for instance, Marcus (2013, 2014), Freier, Schumann and Siedler (2015), Neuenkirch and Tillmann (2016).

12 Results based on propensity score reweighting are available on request.

13 The data allow us to balance on the first and second moment. Cardinal and nominal covariates are balanced on mean and variance, whereas categorical variables need only be balanced on the first moment.
} 
underlying econometric model explains the individual $i$ 's change in life satisfaction between the pre-treatment PASS and post-treatment PASS interviews $\left(\Delta L S=L S_{\text {post }}-L S_{\text {pre }}\right)$ by being part of the treatment group (dummy TREAT), which varies from the first to the fourth DiD approach as described above. Any event leading into or out of subsidized employment must be reflected by an increase or decrease in household income or household size because these two criteria determine the eligibility for income support. For test I our econometric model therefore considers the change in log-point household income $\left(\Delta \ln (y)=\ln \left(y_{\text {post }}\right)-\ln \left(y_{\text {pre }}\right)\right)$ accompanying the transition as well as two dummy variables for changes in household size (SIZEUP, SIZEDOWN). Considering $\Delta \ln (y)$ also allows us to disentangle the non-monetary effect of switching labor market states (e.g. norm effects) from the change of income accompanying these transitions. Wave dummies $(W)$ account for time effects, such as cyclically driven uncertainty about future employment stability. The basic version of the model finally includes the average change in $L S$ of the reference group $(\alpha)$ and an individual error term $\varepsilon$ :

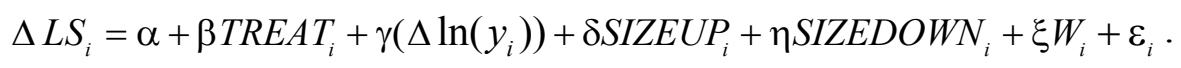

SIZEUP and SIZEDOWN may not perfectly control for life satisfaction effects of events that produce changes in household size. For instance, divorce leading the partner to move out might affect well-being differently than a child moving out to get married. We will therefore conduct robustness checks for all tests based on pre and post one-person households only.

Tests II.1 and II.2 are based on samples of workers who are employed at both the pretreatment and the post-treatment PASS interview. Here, we can expand the model with further controls concerning occupational changes between the two points in time. In particular, job mobility (new job: $N J$, see Chadi and Hetschko 2016a,b) and changes in working hours ( $\Delta h=h_{\text {post }}-h_{\text {pre }}$, see Rätzel 2012, Wunder and Heineck 2013) might alter well-being and could thus confound the genuine effects of switching between subsidized and regular employment. We also control for changes in work strain due to occupational changes, $\Delta s=s_{\text {post }}-s_{\text {pre }}$. Recall that we merge a very detailed work strain index with our data. This index aggregates the strain originating from manifold working conditions, such as the mental burden of occupation-specific uncertainty about future employment stability and the physical burden of manual work (see Section 3). This control variable hence allows us to overcome the problem that subsidized employment may differ from regular employment in the characteristics of work. The modified model is

$$
\begin{aligned}
\Delta L S_{i}= & \alpha+\beta \text { TREAT }_{i}+\gamma\left(\Delta \ln \left(y_{i}\right)\right)+\text { SSIZEUP }_{i}+\eta \text { SIZEDOWN }_{i} \\
& +\theta N J_{i}+\kappa\left(\Delta s_{i}\right)+\lambda\left(\Delta h_{i}\right)+\xi W_{i}+\varepsilon_{i} .
\end{aligned}
$$




\section{Results}

\subsection{Do the unemployed benefit from subsidized employment?}

We track individuals who experience a switch from unemployment to subsidized employment (test I.1) or vice versa (test I.2). Figure 2 depicts the average life satisfaction levels of the treatment group before and after the switch and of the balanced control group, which continues to stay in the respective initial labor market status. Workers who transition from unemployment to subsidized employment experience a strong increase in life satisfaction. This change significantly exceeds the respective change in life satisfaction of the balanced control group by 0.697 points $(p<0.01$; without balancing, this DiD would be $0.682, p<0.01$ ). The opposite transition (Test I.2) yields a corresponding pattern. Subsidized workers who become unemployed experience a drop in life satisfaction whereas the well-being level of the control group remains quite stable. The difference in the life satisfaction change between treatment and control group is -0.277 ( $p<0.05$; without balancing, this DiD would be $-0.315, p<0.05$ ). In sum, our mean analyses suggest finding a job (losing work) restores (decreases) workers' life satisfaction even though the new (old) job is (was) subsidized.

Figure 2: Average changes in life satisfaction between subsidized jobs and unemployment

Test I.1
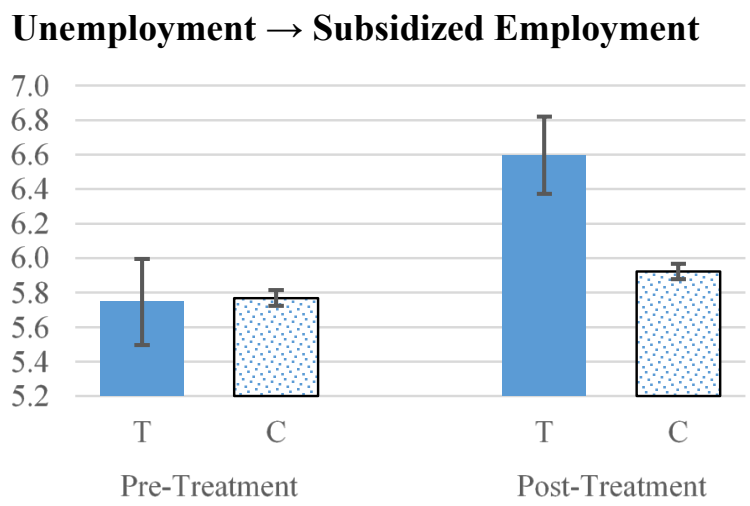

Test I.2
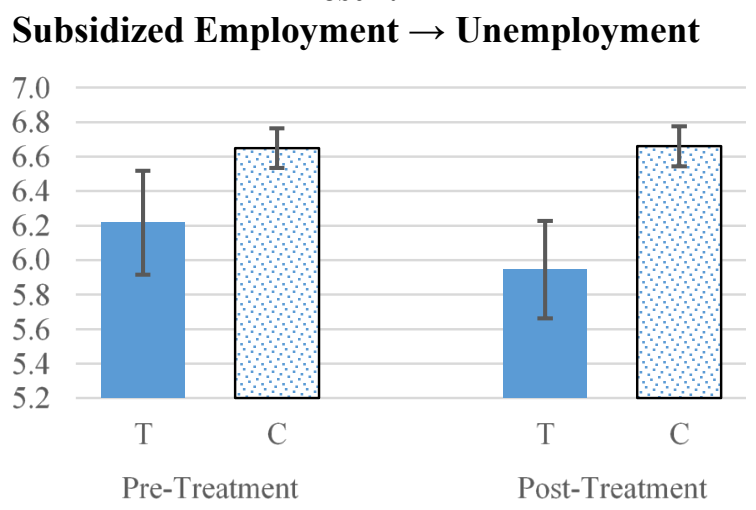

Source. PASS 2007-2014.

Note: bars illustrate the average life satisfaction level of the respective treatment groups (T) and control groups $(C)$. Whiskers denote $95 \%$ confidence intervals.

As explained in Section 4.3, multiple OLS regression analyses allow us to disentangle the monetary component of the well-being effect of transitions between labor market states from the non-monetary component. In addition, the true life satisfaction effect of the transition will be better approached when well-being effects of coincident changes in the UB II eligibility criteria are controlled for. According to columns 1 and 2 of Table 1, changes in disposable household income and household size in the empirical model hardly affect the DiD estimate of 
switching from unemployment to subsidized employment. The effect remains substantially and highly statistically significant. Columns 3 and 4 show that leaving subsidized employment and entering unemployment reduces life satisfaction compared to remaining in subsidized employment, while controlling for changes in income and household size barely affects this result.

Table 1: DiD unemployment and subsidized employment

\begin{tabular}{lcccc} 
& \multicolumn{2}{c}{$\begin{array}{c}\text { Test I.1 Unemployment } \rightarrow \\
\text { Dependent variable: } \Delta \text { LS }\end{array}$} & \multicolumn{2}{c}{$\begin{array}{c}\text { Test I.2 Subsidized Employment } \rightarrow \\
\text { Unemployment }\end{array}$} \\
\hline & 1 & 2 & 3 & 4 \\
\hline treatment & $0.699^{* * *}$ & $0.638^{* * *}$ & $-0.312^{*}$ & $-0.296^{*}$ \\
& $(0.116)$ & $(0.118)$ & $(0.165)$ & $0.171)$ \\
$\Delta$ disposable income $(\ln )$ & & $0.425^{* * *}$ & & $(0.231)$ \\
& & $(0.156)$ & & -0.043 \\
$(+)$ person in household & & 0.039 & & $(0.349)$ \\
& & $(0.345)$ & & -0.070 \\
$(-)$ person in household & & 0.126 & -0.164 & -0.171 \\
& & $(0.209)$ & $(0.222)$ & $(0.223)$ \\
Constant & $0.338^{* * *}$ & $0.345^{* * *}$ & yes & yes \\
wave controls & $(0.129)$ & $(0.133)$ & 0.013 & 0.014 \\
\hline $\mathrm{R}^{2}$ & Yes & yes & 1,076 & 1,076 \\
$\mathrm{~N}$ & 0.036 & 0.042 & & \\
\hline \hline
\end{tabular}

Source. PASS 2007-2014.

Note: ${ }^{*}$ denotes significance at the $10 \%$ level, ${ }^{* *}$ at the $5 \%$ level and ${ }^{* * *}$ at the $1 \%$ level. Robust standard errors in parentheses. The control group consists of individuals who are still unemployed (columns 1 and 2) and of individuals who remain in subsidized employment (columns 3 and 4). Both control groups have been reweighted by pre-treatment characteristics from the categories income and wealth, socio-demographic characteristics and health status (for the details see Tables A1 and A2 in the Appendix). With respect to leaving unemployment (columns 1 and 2), EB is additionally conducted based on previous unemployment duration. Regarding leaving subsidized employment (columns 3 and 4), EB also accounts for previous employment duration. The constant states a change in life satisfaction of a control group individual without any change in disposable household income or household size.

Compared to test I.1 and the following tests II.1 and II.2, the life satisfaction gap between the treatment and control groups before the transition from subsidized employment to unemployment is relatively large, even after balancing (compare Figures 2 and 3). Moreover, the treatment effect of entering subsidized employment seems to be more pronounced than that of leaving it. We suspect that job insecurity on the eve of unemployment explains these two circumstances. Previous research has shown that people are fairly well able to foresee losing work beforehand and that the resulting uncertainty about future employment stability reduces life satisfaction (Knabe and Rätzel 2010, Luechinger, Meier and Stutzer 2010, Dickerson and Green 2012). As a result, the well-being change from the pre-treatment point in time to the posttreatment point in time estimated for the treated might be biased positively as part of the effect of becoming unemployed is already anticipated. 
To shed light on this notion, we replicate our test I.2 results based on a subgroup of treated workers whose pre-treatment interview takes place at least about six months before entering unemployment and who should thus be less able to anticipate the transition than treated workers who are interviewed closer to the unemployment spell. It firstly turns out that the control groups' pre-treatment level of life satisfaction differs much less from that of treated workers if interviewed at least six months before job loss $(\Delta=0.22, p<0.20)$ compared to less than six months $(\Delta=0.58, p<0.01)$. Secondly, the treatment effect of column 4 in Table 1 would decrease to $-0.457(p<0.05)$ if only workers interviewed at least about six months before unemployment were considered as the treated. In sum, anticipation seems to play a role in our results I.2 on transitions from subsidized employment to unemployment.

Altogether, tests I.1 and I.2 support our first hypothesis. Unemployment is accompanied by lower well-being than subsidized employment. The benefits of working, such as complying with the social norm to work, seem to render a subsidized job more satisfying than having no job at all, although subsidized employees do not adhere to the norm of making one's own living. Our results thus suggest in-work benefits to be a suitable instrument for restoring the well-being of the unemployed if it fosters their reemployment opportunities. Besides these main insights, we find that life satisfaction does not relate significantly to changes in household size. Furthermore, mainly based on the results of test I.1, disposable income increases life satisfaction.

\subsection{Is subsidized employment equivalent to regular employment?}

Next, we follow workers from regular employment into subsidized employment (test II.1) and from subsidized employment to regular employment (test II.2). To begin with, Figure 3 allows us to derive descriptive results from mean comparison. On average, transitioning from regular employment to subsidized employment reduces satisfaction with life whereas staying regularly employed leaves well-being almost unaffected. The $\mathrm{DiD}$ amounts to -0.238 points $(p<0.01$; without balancing it would be $-0.148, p=0.1$ ). Becoming a regular worker after having been subsidized employed increases well-being. The difference to the change in life satisfaction of people who stay regularly employed is 0.345 ( $p<0.05$; without balancing: $0.295, p<0.05$ ). 
Figure 3: Average changes in life satisfaction between subsidized and regular jobs

Test II.1

Regular Employment $\rightarrow$ Subsidized Employment

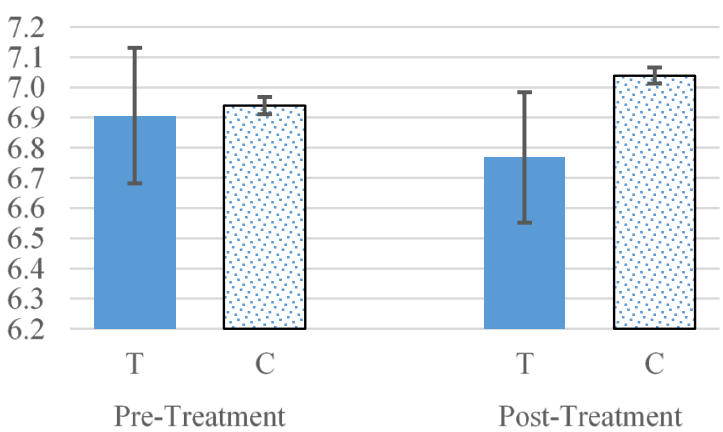

Test II.2

Subsidized Employment $\rightarrow$ Regular Employment

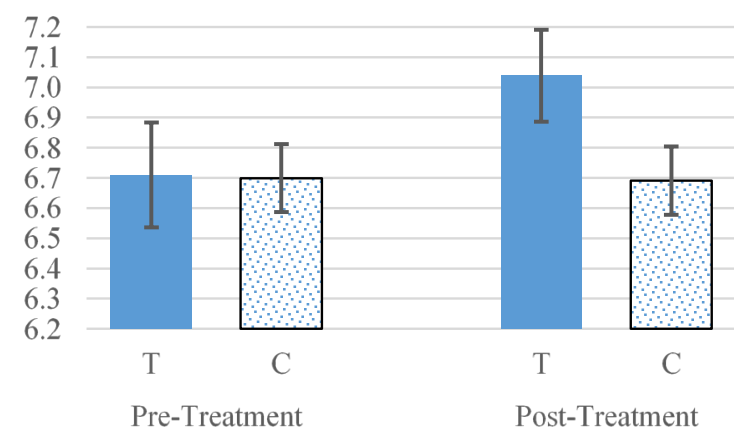

Source. PASS 2007-2014.

Note: Bars illustrate the average life satisfaction level of the respective treatment groups (T) and control groups $(C)$. Whiskers denote $95 \%$ confidence intervals.

Table 2 reports the results of multiple regression analyses considering changes in household size, disposable income and occupational characteristics. For test II.1, adding these controls reduces the effect size only slightly, but at the cost of statistical significance (columns 1-3). Controls for test II.2 also reduce the coefficient of leaving in-work benefit receipt, but it continues to be statistically significant (columns 4-6). In sum, the empirical analyses on transitions between subsidized employment and regular employment provide some evidence in support of hypothesis 2 . The fact that subsidized employees do not adhere to the nondependency norm could explain why they enjoy lower well-being than regular workers.

In addition, we find some evidence for a positive role of income in workers' well-being and for a honeymoon effect of starting a new job (test II.2). The life satisfaction question is answered enthusiastically in particular immediately after the beginning of new employment (3 months after beginning a new employment spell). ${ }^{14}$ In addition, overall well-being decreases with a decline in work strain.

\footnotetext{
${ }^{14}$ Interestingly, the effect is stronger compared to the recent study by Chadi and Hetschko (2016b). An important difference in the methodologies might be that low-paid workers are oversampled in our database (because of the PASS' focus on UB II), whereas Chadi and Hetschko (2016b) analyze representative German panel data. Perhaps the honeymoon effect is stronger among workers who receive relatively low wages.
} 
Table 2: DiD regular employment and subsidized employment

\begin{tabular}{|c|c|c|c|c|c|c|}
\hline \multirow[t]{2}{*}{ Dependent variable: $\Delta L S$} & \multicolumn{3}{|c|}{$\begin{array}{c}\text { Test II.1: Regular employment } \rightarrow \\
\text { Subsidized employment }\end{array}$} & \multicolumn{3}{|c|}{$\begin{array}{c}\text { Test II.2: Subsidized employment } \rightarrow \\
\text { Regular employment }\end{array}$} \\
\hline & 1 & 2 & 3 & 4 & 5 & 6 \\
\hline Treatment & $\begin{array}{c}-0.229^{*} \\
(0.125)\end{array}$ & $\begin{array}{c}-0.172 \\
(0.133)\end{array}$ & $\begin{array}{c}-0.185 \\
(0.134)\end{array}$ & $\begin{array}{l}0.341^{* * *} \\
(0.111)\end{array}$ & $\begin{array}{c}0.282^{* *} \\
(0.113)\end{array}$ & $\begin{array}{c}0.233^{* *} \\
(0.113)\end{array}$ \\
\hline$\Delta$ disposable income $(\ln )$ & & $\begin{array}{l}0.262 \\
(0.160)\end{array}$ & $\begin{array}{l}0.265 \\
(0.161)\end{array}$ & & $\begin{array}{l}0.385^{* * *} \\
(0.132)\end{array}$ & $\begin{array}{c}0.418^{* * *} \\
(0.132)\end{array}$ \\
\hline$(+)$ person in household & & $\begin{array}{c}-0.280 \\
(0.242)\end{array}$ & $\begin{array}{c}-0.279 \\
(0.245)\end{array}$ & & $\begin{array}{l}0.137 \\
(0.381)\end{array}$ & $\begin{array}{l}0.166 \\
(0.381)\end{array}$ \\
\hline (-) person in household & & $\begin{array}{c}-0.206 \\
(0.274)\end{array}$ & $\begin{array}{c}-0.196 \\
(0.274)\end{array}$ & & $\begin{array}{c}-0.012 \\
(0.206)\end{array}$ & $\begin{array}{l}0.006 \\
(0.205)\end{array}$ \\
\hline new job $(<4$ months $)$ & & & $\begin{array}{l}0.109 \\
(0.305)\end{array}$ & & & $\begin{array}{l}0.580^{* * *} \\
(0.216)\end{array}$ \\
\hline new job (4 - 12 months) & & & $\begin{array}{l}0.122 \\
(0.187)\end{array}$ & & & $\begin{array}{l}0.150 \\
(0.161)\end{array}$ \\
\hline$\Delta$ change in work strain & & & $\begin{array}{r}0.053 \\
(0.070)\end{array}$ & & & $\begin{array}{c}-0.129^{* *} \\
(0.060)\end{array}$ \\
\hline$\Delta$ change in hours per week & & & $\begin{array}{c}-0.004 \\
(0.007)\end{array}$ & & & $\begin{array}{l}0.003 \\
(0.009)\end{array}$ \\
\hline Constant & $\begin{array}{l}0.172 \\
(0.162)\end{array}$ & $\begin{array}{l}0.129 \\
(0.157)\end{array}$ & $\begin{array}{l}0.134 \\
(0.157)\end{array}$ & $\begin{array}{c}-0.181 \\
(0.193)\end{array}$ & $\begin{array}{c}-0.234 \\
(0.206)\end{array}$ & $\begin{array}{r}-0.256 \\
(0.196)\end{array}$ \\
\hline wave controls & Yes & Yes & yes & yes & yes & yes \\
\hline $\mathrm{R}^{2}$ & 0.013 & 0.020 & 0.020 & 0.017 & 0.025 & 0.038 \\
\hline $\mathrm{N}$ & 13,980 & 13,980 & 13,980 & 1,211 & 1,211 & 1,211 \\
\hline
\end{tabular}

Source. PASS 2007-2014.

Note: ${ }^{*}$ denotes significance at the $10 \%$ level, ${ }^{* *}$ at the $5 \%$ level and ${ }^{* * *}$ at the $1 \%$ level. Robust standard errors in parentheses. The control group consists of individuals that remain regularly employed (columns 1-3) and individuals that remain in subsidized employment (columns 4-6). The control groups have been reweighted by pre-treatment characteristics from the categories income and wealth, socio-demographic characteristics, health status and job characteristics (for details see Appendix Tables A3 and A4). The constant states a change in life satisfaction of a control group individual that does not experience any change in disposable household income, household size, work strain or working hours and has not recently switched jobs.

\subsection{Regular employment, unemployment and the non-dependency norm}

So far, our results indicate $L S($ Unemployed, $\bullet)<L S($ Subsidized employed, $\bullet)$ and $L S($ Subsidized employed, $\bullet)<L S($ Regularly employed, $\bullet)$. For reasons of consistency, we should expect $L S($ Unemployed, $\bullet)<L S($ Regularly employed, $\bullet)$ from a similar analysis of the transitions between regular employment and unemployment. Hence, applying an additional test III, we can further elaborate the impact of the non-dependency norm from a different angle. Not all of the unemployed necessarily violate this norm. Many unemployed people rely on statutory unemployment insurance benefits (UB I) while others are supported by family members since they live in households with too high an income to be eligible to receive UB II. In these cases, unemployed workers do not live off welfare benefits and may thus not feel they violate the non-dependency norm. We therefore conjecture that the well-being effect of transitioning from regular employment to unemployment is more detrimental for UB II recipients than for those workers who do not receive UB II when unemployed. By the same logic, we expect that leaving unemployment for a regular job will increase life satisfaction more 
if workers have received UB II while unemployed compared to workers who have not. Table 3 displays the results for both transitions (tests III.1 and III.2). Becoming unemployed as a regular worker is detrimental in general. The pure change in life satisfaction has almost the same magnitude as for subsidized workers who become unemployed (see Table 3, column 1). In column 2, being a welfare recipient when unemployed is indicated by the interaction terms. The reduction in life satisfaction is quantitatively less severe for the non-dependent unemployed $(p<0.06)$.

Table 3: DiD unemployment and regular employment

Test III. 1: Regular employment $\rightarrow$

Dependent variable: $\triangle L S$

\begin{tabular}{|c|c|c|c|c|}
\hline & 1 & 2 & 3 & 4 \\
\hline Treatment & $\begin{array}{c}-0.459^{* * *} \\
(0.084)\end{array}$ & & $\begin{array}{c}0.839^{* * *} \\
(0.075)\end{array}$ & \\
\hline Treatment $*$ UB I / no transfers & & $\begin{array}{c}-0.368^{* * *} \\
(0.091)\end{array}$ & & \\
\hline Treatment * UB II & & $\begin{array}{c}-0.661^{* * *} \\
(0.152)\end{array}$ & & \\
\hline Treatment * UB I / no transfers before & & & & $\begin{array}{c}0.664^{* * *} \\
(0.106)\end{array}$ \\
\hline Treatment $*$ UB II before & & & & $\begin{array}{c}0.946^{* * *} \\
(0.090)\end{array}$ \\
\hline$\Delta$ disposable income $(\ln )$ & $\begin{array}{c}0.256^{* *} \\
(0.104)\end{array}$ & $\begin{array}{c}0.228^{* *} \\
(0.105)\end{array}$ & $\begin{array}{c}0.370^{* * *} \\
(0.103)\end{array}$ & $\begin{array}{c}0.347^{* * * *} \\
(0.102)\end{array}$ \\
\hline$(+)$ person in household & $\begin{array}{l}0.176 \\
(0.184)\end{array}$ & $\begin{array}{l}0.165 \\
(0.184)\end{array}$ & $\begin{array}{l}0.102 \\
(0.164)\end{array}$ & $\begin{array}{l}0.096 \\
(0.163)\end{array}$ \\
\hline$(-)$ person in household & $\begin{array}{l}0.120 \\
(0.150)\end{array}$ & $\begin{array}{l}0.108 \\
(0.149)\end{array}$ & $\begin{array}{c}-0.152 \\
(0.153)\end{array}$ & $\begin{array}{c}-0.139 \\
(0.154)\end{array}$ \\
\hline Constant & $\begin{array}{c}-0.189 \\
(0.125)\end{array}$ & $\begin{array}{c}-0.187 \\
(0.125)\end{array}$ & $\begin{array}{c}0.283^{* * *} \\
(0.093)\end{array}$ & $\begin{array}{c}0.272^{* * *} \\
(0.092)\end{array}$ \\
\hline Wave controls & yes & yes & yes & yes \\
\hline $\mathrm{R}^{2}$ & 0.036 & 0.039 & 0.073 & 0.075 \\
\hline $\mathrm{N}$ & 14,454 & 14,454 & 8,663 & 8,663 \\
\hline
\end{tabular}

Source. PASS 2007-2014.

Note: ${ }^{*}$ denotes significance at the $10 \%$ level, ${ }^{* *}$ at the $5 \%$ level and ${ }^{* * *}$ at the $1 \%$ level. Robust standard errors in parentheses. The control group consists of individuals that are still regularly employed (columns 1 and 2) and individuals that remain unemployed (columns 3 and 4). For test I.1 (columns 1 and 2), the control groups have been reweighted by pre-treatment characteristics from the categories income and wealth, socio-demographic characteristics, health status, and job characteristics. For test I.2 (columns 3 and 4), EB also considers pre-treatment unemployment duration. The constant states a change in life satisfaction of a control group individual without any change in disposable household income or household size.

Switching from unemployment to regular employment increases life satisfaction. The effect seems stronger than for the transition to a subsidized job (see Table 1). For those leaving UB II receipt, the rise in life satisfaction is significantly larger than for formerly unemployed workers who have lived off other sources of income. Altogether, these results are consistent with our main results, implying $L S($ Unemployed, $\bullet)<L S($ Regularly employed, $\bullet)$. With respect to the 
unemployed, our findings also underline the notion of a non-dependency norm and its expected negative role in workers' well-being.

\subsection{Identity stigma and treatment stigma}

Jobcenters try to incentivize transfer recipients to overcome welfare dependency. For that purpose, the Jobcenters are to make frequent appointments, send requests and contact recipients by phone. By not answering these requests appropriately recipients take the risk of being sanctioned by way of benefit deductions. Thus, frequent calls of the Jobcenter render noncompliance with the non-dependency norm very salient to subsidized workers. They might feel stigmatized as being unable to make their own living due to such treatment, i.e. they suffer from the treatment stigma à la Stuber and Schlesinger (2006). In the following, we consider this notion in our analyses by incorporating whether subsidized workers have contact with the Jobcenter or not. ${ }^{15}$

The information about contacts to the Jobcenter is available for all the PASS waves, except wave 7. In the course of test I.1 (transition from unemployment to subsidized employment), we add a further control variable accounting for the qualitative change in personal Jobcenter contacts. This control ( $\triangle J o b C e n)$ equals 1 if no pre-treatment contacts to the Jobcenter are reported before the transition, but afterwards, -1 in the reverse case and 0 otherwise. ${ }^{16}$

As columns 1 and 2 of Table 4 reveal, there is a close resemblance, based on the data that allow us to construct $\triangle J o b C e n$, to the original treatment effect for the transition from unemployment to subsidized employment. In column 3, we consider $\Delta J_{o b C e n}$ as well as an interaction of $\triangle J o b C e n$ and the treatment dummy. It turns out that the change in life satisfaction of workers who stay unemployed decreases in $\triangle J o b C e n$. Becoming subsidized employed might strengthen this effect, although the interaction effect is not statistically significant. If anything, $\triangle J o b C e n$ seems to lower the positive treatment effect of entering subsidized employment. With the same extension, test I.2 yields consistent findings, but we neither report nor interpret these as the interaction effect relies on less than 30 observations.

\footnotetext{
15 In principle, contacts can also be initiated by the welfare recipients. Personal contacts depend on duration of UB II receipt, household context and the discretionary decisions of the Jobcenters' case managers.

16 Estimations accounting for the change in overall Jobcenter contacts would lead to the same conclusions.
} 
Table 4: The role of individual contacts to Jobcenter

Test I.1 Unemployment $\rightarrow$

Dependent variable: $\Delta \mathrm{LS}$

Subsidized employment

Test II.1 Regular employment $\rightarrow$ Subsidized employment

\begin{tabular}{|c|c|c|c|c|c|c|}
\hline & 1 & 2 & 3 & 4 & 5 & 6 \\
\hline Treatment & $\begin{array}{c}0.638^{* * *} \\
(0.118)\end{array}$ & $\begin{array}{c}0.584^{* * *} \\
(0.152)\end{array}$ & $\begin{array}{c}0.609^{* * *} \\
(0.150)\end{array}$ & $\begin{array}{c}-0.185 \\
(0.134)\end{array}$ & $\begin{array}{c}-0.161 \\
(0.160)\end{array}$ & $\begin{array}{c}-0.431^{* *} \\
(0.173)\end{array}$ \\
\hline $\begin{array}{l}\text { Change in Jobcenter } \\
\text { contacts }\end{array}$ & & & $\begin{array}{c}-0.188^{* *} \\
(0.092)\end{array}$ & & & \\
\hline $\begin{array}{l}\text { Treatment } \times \text { change in } \\
\text { Jobcenter contacts }\end{array}$ & & & $\begin{array}{c}-0.186 \\
(0.376)\end{array}$ & & & \\
\hline$\Delta$ disposable income $(\ln )$ & $\begin{array}{c}0.425^{* * *} \\
(0.156)\end{array}$ & $\begin{array}{c}0.491^{* * *} \\
(0.186)\end{array}$ & $\begin{array}{c}0.473^{* *} \\
(0.186)\end{array}$ & $\begin{array}{c}0.267^{*} \\
(0.161)\end{array}$ & $\begin{array}{c}0.417^{* *} \\
(0.180)\end{array}$ & $\begin{array}{c}0.318^{*} \\
(0.177)\end{array}$ \\
\hline$(+)$ person in household & $\begin{array}{l}0.039 \\
(0.345)\end{array}$ & $\begin{array}{l}0.232 \\
(0.493)\end{array}$ & $\begin{array}{l}0.252 \\
(0.474)\end{array}$ & $\begin{array}{c}-0.279 \\
(0.246)\end{array}$ & $\begin{array}{c}-0.297 \\
(0.350)\end{array}$ & $\begin{array}{c}-0.119 \\
(0.386)\end{array}$ \\
\hline$(-)$ person in household & $\begin{array}{l}0.126 \\
(0.209)\end{array}$ & $\begin{array}{c}-0.111 \\
(0.277)\end{array}$ & $\begin{array}{c}-0.118 \\
(0.277)\end{array}$ & $\begin{array}{c}-0.191 \\
(0.273)\end{array}$ & $\begin{array}{l}0.075 \\
(0.228)\end{array}$ & $\begin{array}{l}0.139 \\
(0.223)\end{array}$ \\
\hline new job ( $<4$ months $)$ & & & & $\begin{array}{l}0.109 \\
(0.306)\end{array}$ & $\begin{array}{l}0.146 \\
(0.366)\end{array}$ & $\begin{array}{l}0.022 \\
(0.274)\end{array}$ \\
\hline new job (4 - 12 months) & & & & $\begin{array}{l}0.122 \\
(0.187)\end{array}$ & $\begin{array}{l}0.250 \\
(0.220)\end{array}$ & $\begin{array}{l}0.304 \\
(0.220)\end{array}$ \\
\hline$\Delta$ Change in work strain & & & & $\begin{array}{l}0.053 \\
(0.070)\end{array}$ & $\begin{array}{l}0.064 \\
(0.081)\end{array}$ & $\begin{array}{l}0.084 \\
(0.090)\end{array}$ \\
\hline $\begin{array}{l}\Delta \text { Change in hours per } \\
\text { week }\end{array}$ & & & & $\begin{array}{c}-0.004 \\
(0.007)\end{array}$ & $\begin{array}{c}-0.007 \\
(0.008)\end{array}$ & $\begin{array}{c}-0.007 \\
(0.008)\end{array}$ \\
\hline Constant & $\begin{array}{c}0.344^{* * *} \\
(0.133)\end{array}$ & $\begin{array}{c}0.363^{* * *} \\
(0.137)\end{array}$ & $\begin{array}{c}0.334^{* *} \\
(0.136)\end{array}$ & $\begin{array}{l}0.134 \\
(0.158)\end{array}$ & $\begin{array}{l}0.092 \\
(0.159)\end{array}$ & $\begin{array}{l}0.228 \\
(0.167)\end{array}$ \\
\hline wave controls $^{\dagger}$ & yes & yes & yes & yes & yes & yes \\
\hline $\mathrm{R}^{2}$ & 0.042 & 0.042 & 0.046 & 0.020 & 0.027 & 0.040 \\
\hline $\mathrm{N}$ & 8,317 & 4,928 & 4,928 & 13,980 & 11,165 & 11,120 \\
\hline
\end{tabular}

Source: PASS 2007-2014.

Note: ${ }^{*}$ denotes significance at the $10 \%$ level, ${ }^{* *}$ at the $5 \%$ level and ${ }^{* * *}$ at the $1 \%$ level. Robust standard errors in parentheses. Control groups are reweighted by EB (see Tables 1, 2, A1 and A3 for detailed descriptions). ${ }^{\top}$ The wave controls include all waves in columns 1 and 4, from 2 to 6 in columns 2 and 3 as well as from 2 to 6 plus wave 8 in columns 5 and 6. Column 1 (4) repeats column 2 from Table 1 (column 3 from Table 2).

We cannot conduct the same analysis for test II since regular employees do not report Jobcenter contact at all. However, in the case of test II.1 we can utilize the fact that some workers get in contact with the Jobcenter when becoming subsidized employed while others do not. Columns 4 and 5 of Table 4 facilitate a comparison between the treatment coefficients based on the whole sample (from Table 2) and a reduced sample including data about Jobcenter contacts. Both effects are negative, though not statistically significant. In column 6, we exclude 45 workers who become subsidized employees and do not report getting in contact with the Jobcenter. This enlarges the negative treatment effect, which is now statistically significant. Thus, the transition from regular employment to subsidized employment is clearly negative for life satisfaction if accompanied by Jobcenter contacts. A similar analysis for test II. 2 is not feasible as all workers who transition from subsidized employment to regular employment report pre-treatment Jobcenter contacts. 


\subsection{Robustness checks}

As mentioned above, we cannot fully rule out that the impact of changes in household composition confound our treatment effects. A related threat to our identification strategy could come from the spillover effects of changes in the lives of other household members, such as spousal unemployment (Clark 2003, Knabe, Schöb and Weimann 2015), which can cause employed workers to switch from 'regular' to 'subsidized' employment. To eliminate these issues that arise from the fact that other people living in the same household can make somebody enter or exit UB II receipt, we estimate test I and test II separately for one-adult households only. The shrinking case number inflates our standard errors. Nevertheless, we find results very similar in sign and magnitude to those before (Table 5). ${ }^{17}$

Table 5: Subgroup analysis for single adult households

Dependent variable: $\Delta L S$

\begin{tabular}{lcccc}
\hline & Test I.1 & Test I.2 & Test II.1 & Test II.2 \\
\hline Treatment & $0.583^{* * *}$ & -0.266 & -0.261 & $0.508^{* *}$ \\
& $(0.150)$ & $(0.284)$ & $(0.199)$ & $(0.206)$ \\
$\Delta$ disposable income $(\ln )$ & $0.659^{* * *}$ & $0.565^{* *}$ & $0.801^{* * *}$ & $0.571^{* *}$ \\
& $(0.186)$ & $(0.252)$ & $(0.247)$ & $(0.245)$ \\
Full set of controls & yes & Yes & yes & yes \\
\hline $\mathrm{R}^{2}$ & 0.069 & 0.060 & 0.065 & 0.097 \\
$\mathrm{~N}$ & 4,844 & 458 & 3,770 & 525 \\
\hline
\end{tabular}

Source: PASS 2007-2014.

Note: The table reports the coefficients of tests I.1, I.2, II.1, II.2. for single adult households at $t-1$ and tonly, i.e. one single adult or single parents with the same number of dependent children.

Even two decades after reunification, traces of the division of Germany can still be found. East Germans receive lower wages and, therefore, are more likely to rely on in-work benefits. Hence, the intensity of the non-dependency norm may be weaker in the Eastern part such that noncompliance with this norm is less harmful to workers' well-being compared to the Western part (Chadi 2014). In line with this notion, we find more pronounced treatment effects for West Germans who transition between subsidized employment and regular employment.

Both the norm to work and the non-dependency norm may be stronger for men than for women as the former are more likely to identify with the breadwinner role. Becoming reemployed increases life satisfaction for males more (Test I.1) and men are also more depressed when losing a subsidized job (Test I.2). Test II shows that females do indeed suffer less from becoming subsidized employed, while reentering regular employment does not show gender differences.

\footnotetext{
${ }^{17}$ As for all of the robustness checks, detailed results are available on request.
} 
One necessary condition for unbiased DiD estimates is that the life satisfaction of the treatment group and that of the control group follow a common trend. We can analyze this issue by extending the investigation period to the second-last pre-treatment year (which we name ' $t-2$ '). Figure A1 in the Appendix shows that all the control groups follow the same trends in life satisfaction as the treatment groups until the pre-treatment PASS interview (which we name ' $t-1$ ').

\section{Concluding discussion}

In-work benefits help workers to overcome the extraordinary misery of unemployment. However, workers may still feel dependent on public support as they remain unable to make their own living. Our results support both views. The transition from unemployment into subsidized employment increases life satisfaction by more than what is explainable by the associated change in income. Bringing people back to work thus allows them to regain the nonmonetary benefits of working, such as complying with the social norm to work. The fact that the transition from subsidized employment into regular employment also yields an improvement in life satisfaction beyond the income effect implies that subsidized employment does not fully remove the loss of well-being caused by an unemployment experience associated with welfare dependency. Being employed but having to rely on income support leaves people dependent on public transfers and thus does not allow them to adhere to the non-dependency norm.

Our results can explain why some eligible workers do not apply for welfare (Bruckmeier et al. 2013). The subsidy may not compensate for the well-being loss caused by non-compliance with the norm to make a living by one's own effort. Closely related to this, such a norm might also make it socially undesirable to receive UB II. This could explain why some people misreport not to receive the benefits to the PASS survey (Kreuter, Müller and Trappmann 2010, Bruckmeier, Müller and Riphahn 2014). These workers probably suffer from receiving UB II the most as they are even willing to hide this circumstance from an anonymous survey. As these people are not part of the group of subsidized workers in our samples, although they belong to this group in reality, our estimations should be interpreted as a lower bound of the true wellbeing difference between regular employment and subsidized employment.

Our findings imply that employment subsidies are beneficial if they bring people back into employment. They offset, at least partly, the harm done by involuntary unemployment. However, in-work benefits fail to make workers as well off as those who are regularly employed. This will be desirable if the policy is primarily designed as a stepping stone to bring 
involuntarily unemployed people back into regular work in the long run. For instance, starting a low-paid job makes it easier for poorly educated workers to get well-paid in the future than staying unemployed (Knabe and Plum 2013). They may accumulate human capital and signal their motivation to work and thus encourage employers to hire them rather than unemployed workers. The fact that these employment relationships realize may have two complementary supply-side reasons, the monetary incentive to receive a higher wage and the non-monetary incentive to overcome welfare dependency.

If these employment relationships do not realize, however, in-work benefits will permanently fund a stable group of working poor that are not able to find a regular job. Such a redistribution scheme would then come at a permanent non-negligible well-being cost for the 'beneficiaries'. In this case, a cautious policy recommendation is to apply a policy that eliminates the detrimental effect of norm violation while coming at similar cost for tax payers and yielding similar allocative effects on reemployment probabilities. In particular, it seems necessary to replace individually determined income support by general income redistribution schemes such as a negative income tax. In the same vein, reducing social security contributions at the lower end of the wage distribution can diminish perceived dependence on the welfare state and the negative stigma effects from non-dependency norm violation. 


\section{References}

Besley, Timothy and Stephen Coate (1992): "Understanding welfare stigma: Taxpayer resentment and statistical discrimination", Journal of Public Economics 48(2), 165-183.

Blanchflower, David G. and Andrew J. Oswald (2004): "Well-being over time in Britain and the USA", Journal of Public Economics 88(7-8), 1359-1386.

Blundell, Richard (2000): "Work incentives and 'in-work' benefit reforms: A review", Oxford Review of Economic Policy 16(1), 27-44.

Blundell, Richard and Hilary W. Hoynes (2004): "Has 'In-Work' Benefit Reform Helped the Labor Market?", in: David Card, Richard Blundell, Richard B. Freeman (eds.): Seeking a Premier Economy: The Economic Effects of British Economic Reforms, 1980-2000, University of Chicago Press: Chicago, 411-459.

Bonin, Holger and Ulf Rinne (2014): “'Beautiful Serbia' - objective and subjective outcomes of active labour market policy in a transition economy", Economics of Transition 22(1), 4367.

Brewer, Mike, Alan Duncan, Andrew Shephard and María José Suárez (2006): "Did working families' tax credit work? The impact of in-work support on labour supply in Great Britain", Labour Economics 13(6), 699-720.

Bruckmeier, Kerstin, Gerrit Müller and Regina T. Riphahn (2014): "Who misreports welfare receipt in surveys?", Applied Economics Letters 21(12), 812-816.

Bruckmeier, Kerstin, Johannes Pauser, Ulrich Walwei and Jürgen Wiemers (2013): "Simulationsrechnungen zum Ausmaß der Nicht-Inanspruchnahme von Leistungen der Grundsicherung", IAB Forschungsbericht 5.

Caliendo, Marco and Sabine Kopeinig (2008): "Some practical guidance for the implementation of Propensity Score Matching", Journal of Economic Surveys 22(1), 31-72.

Chadi, Adrian (2012): "Employed but still unhappy? On the relevance of the social work norm", Schmollers Jahrbuch: Journal of Applied Social Science Studies 123(353), 1-26.

Chadi, Adrian (2014): "Regional unemployment and norm-induced effects on life satisfaction", Empirical Economics 46(3), 1111-1141.

Chadi, Adrian and Clemens Hetschko (2016a): "Flexibilization without hesitation? Temporary contracts and job satisfaction", Oxford Economic Papers 68(1), 217-237.

Chadi, Adrian and Clemens Hetschko (2016b): How Job Changes Affect People's Lives Evidence from Subjective Well-being Data, CESifo Working Papers No. 5929.

Chetty, Raj, John N. Friedman and Emmanuel Saez (2013): "Using Differences in Knowledge Across Neighborhoods to Uncover the Impacts of the EITC on Earnings", American Economic Review 103(7), 2683-2721.

Clark, Andrew E. (2003): "Unemployment as a social norm: Psychological evidence from panel data", Journal of Labor Economics 21(2), 323-351.

Dickerson, Andy and Francis Green (2012): "Fears and realisations of employment insecurity", Labour Economics 19(2), 98-210.

Dorsett, Richard and Andrew J. Oswald (2014): Human well-being and in-work benefits: a randomized controlled trail, Warwick Economic Research Papers No. 1038.

Elster, Jon (1989): "Social norms and economic theory", Journal of Economic Perspectives 3(4), 99-117.

Freier, Ronny, Mathias Schumann and Thomas Siedler (2015): "The earnings returns to graduating with honors - Evidence from law graduates", Labour Economics 34, 39-50.

Frijters, Paul and Tony Beatton (2012): "The mystery of the U-shaped relationship between happiness and age", Journal of Economic Behavior and Organization 82(2-3), 525-542.

Hainmueller, Jens (2012): "Entropy balancing for causal effects: A multivariate reweighting method to produce balanced samples in observational studies", Political Analysis 20, 25-46.

Hainmueller, Jens and Yiqing Xu (2013): "Ebalance: A Stata package for entropy balancing", Journal of Statistical Software 54(7), 1-18.

Hetschko, Clemens, Andreas Knabe and Ronnie Schöb (2014): “Changing Identity: Retiring from Unemployment”, Economic Journal 124(575), 149-166.

Kassenboehmer, Sonja C. and John P. Haisken-DeNew (2009): Social jealousy and stigma negative externalities of social assistance payments in Germany, Ruhr Economic Papers No. 117.

Knabe, Andreas and Alexander Plum (2013): "Low-wage jobs - springboard to high-paid ones?", Labour 27(3), 310-330. 
Knabe, Andreas and Steffen Rätzel (2010): "Better an insecure job than no job at all? Unemployment, job insecurity and subjective wellbeing", Economics Bulletin 30(3), 24862494.

Knabe, Andreas and Steffen Rätzel (2011): "Quantifying the psychological costs of unemployment: The role of permanent income", Applied Economics 43(21), 2751-2763.

Knabe, Andreas, Steffen Rätzel, Ronnie Schöb and Joachim Weimann (2010): "Dissatisfied with life but having a good day: Time-use and well-being of the unemployed", Economic Journal 120(547), 867-889.

Knabe, Andreas, Ronnie Schöb and Joachim Weimann (2015): "Partnership, gender roles and the well-being cost of unemployment", Social Indicators Research, doi:10.1007/s11205015-1167-3.

Korpi, Tomas (1997): "Is utility related to employment status? Employment, unemployment, labor market policies and subjective well-being among Swedish youth", Labour Economics 4(2), 125-147.

Kreuter, Frauke, Gerrit Müller and Mark Trappmann (2010): "Nonresponse and measurement error in employment research: Making use of administrative data", Public Opinion Quarterly 74(5), 880-906.

Kroll, Lars E. (2011): "Konstruktion und Validierung eines allgemeinen Index für die Arbeitsbelastung in beruflichen Tätigkeiten auf Basis von ISCO-88 und KldB-92", Methoden, Daten, Analysen (mda) 5(1), 69-90.

Krug, Gerhard (2009): "In-work benefits for low-wage jobs: Can additional income reduce employment stability?", European Sociological Review 25(4), 459-474.

Luechinger, Simon, Stephan Meier and Alois Stutzer (2010): "Why does unemployment hurt the employed?: Evidence from the life satisfaction gap between the public and the private sector", Journal of Human Resources 45(4), 998-1045.

Marcus, Jan (2013): "The effect of unemployment on the mental health of spouses - Evidence from plant closures in Germany", Journal of Health Economics 32(3), 546-558.

Marcus, Jan (2014): "Does job loss make you smoke and gain weight? ", Economica 81(324), 626-648.

Moffitt, Robert (1983): "An economic model of welfare stigma", American Economic Review 73(5), 1023-1035.

Neuenkirch, Matthias and Peter Tillmann (2016): "Does a good central banker make a difference?", Economic Inquiry 54(3), 1541-1560.

Powdthavee, Nattavudh (2007): "Are there geographical variations in the psychological cost of unemployment in South Africa?", Social Indicators Research 80(3), 629-652.

Rätzel, Steffen (2012): "Labour supply, life satisfaction, and the (dis)utility of work", Scandinavian Journal of Economics 114(4), 1160-1181.

Riphahn, Regina T. (2001): "Rational poverty or poor rationality? The take-up of social assistance benefits", Review of Income and Wealth 47(3), 379-398.

Saez, Emmanuel (2002): "Optimal Income Transfer Programs: Intensive versus Extensive Labor Supply Responses", Quarterly Journal of Economics 117(3), 1039-1073.

Schöb, Ronnie (2013): "Unemployment and identity", CESifo Economic Studies 59(1), 149180.

Shields, Michael A. and Stephen Wheatley Price (2005): "Exploring the economic and social determinants of psychological well-being and perceived social support in England", Journal of the Royal Statistical Society: Series A (Statistics in Society) 168(3), 513-537.

Shields, Michael A., Stephen Wheatley Price and Mark Wooden (2009): "Life satisfaction and the economic and social characteristics of neighbourhoods", Journal of Population Economics 22(2), 421-443.

Stuber, Jennifer and Mark Schlesinger (2006): "Sources of stigma for means-tested government programs", Social Science \& Medicine 63(4), 933-945.

Stutzer, Alois and Rafael Lalive (2004): "The role of social work norms in job searching and subjective well-being", Journal of the European Economic Association 2(4), 696-719.

Trappmann, Mark, Jonas Beste, Arne Bethmann and Gerrit Müller (2013): "The PASS panel survey after six waves", Journal for Labour Market Research 46(4), 275-281.

Trappmann, Mark, Stefanie Gundert, Claudia Wenzig and Daniel Gebhardt (2010): "PASS - A household panel survey for research on unemployment and poverty", Schmollers Jahrbuch - Journal of Applied Social Science Studies 130, 609-622. 
Van der Linden, Bruno (2016): "Do in-work benefits work for low-skilled workers?", IZA World of Labor (246), doi: 10.15185/izawol.246.

Whelan, Stephen (2010): "The take-up of means-tested income support", Empirical Economics $39(3), 847-875$.

Winkelmann, Liliana and Rainer Winkelmann (1998): "Why are the unemployed so unhappy? Evidence from panel data", Economica 65(257), 1-15.

Wunder, Christoph and Guido Heineck (2013): "Working time preferences, hours mismatch and well-being of couples: Are there spillovers?", Labour Economics 24, 244-252. 


\section{Appendix}

Table A1: Summary Statistics Test I.1

\begin{tabular}{|c|c|c|c|c|c|}
\hline & Scale & Treatment & Control & Difference & $\begin{array}{c}\text { Control } \\
\text { (Entropy } \\
\text { Balanced) }\end{array}$ \\
\hline \multirow[t]{2}{*}{ Number of observations: } & & $\mathrm{N}=260$ & $\mathrm{~N}=8,057$ & & $\mathrm{~N}=8,057$ \\
\hline & & $\begin{array}{c}\text { mean / share } \\
\text { (std. dev.) }\end{array}$ & $\begin{array}{c}\text { mean / share } \\
\text { (std. dev.) }\end{array}$ & $\begin{array}{l}\text { Control - } \\
\text { Treatment }\end{array}$ & $\begin{array}{c}\text { mean / share } \\
\text { (std. dev.) }\end{array}$ \\
\hline \multicolumn{6}{|l|}{ Life satisfaction } \\
\hline Life satisfaction (mean) & $0-10$ & $\begin{array}{c}5.75 \\
(2.04)\end{array}$ & $\begin{array}{c}5.59 \\
(2.15)\end{array}$ & -0.15 & $\begin{array}{c}5.77 \\
(2.07)\end{array}$ \\
\hline \multicolumn{6}{|l|}{ Income and Wealth } \\
\hline Equivalence income (OECD scale) (mean) & $€$ & $\begin{array}{c}738.58 \\
(193.03)\end{array}$ & $\begin{array}{c}715.13 \\
(262.66)\end{array}$ & -23.45 & $\begin{array}{c}738.09 \\
(193.14)\end{array}$ \\
\hline Savings $<1000 €($ share $)$ & $\%$ & 86.5 & 86.2 & -0.3 & 86.5 \\
\hline Savings $<5000 €($ share $)$ & $\%$ & 8.5 & 8.5 & 0.0 & 8.5 \\
\hline Savings $>5000 €($ share $)$ & $\%$ & 4.2 & 4.5 & 0.3 & 4.2 \\
\hline \multicolumn{6}{|l|}{ Socio-demographic characteristics } \\
\hline Age (mean) & $18-64$ & $\begin{array}{c}40.38 \\
(10.66)\end{array}$ & $\begin{array}{c}45.34 \\
(11.74)\end{array}$ & $4.97^{* * *}$ & $\begin{array}{c}40.35 \\
(10.64)\end{array}$ \\
\hline Adults in household (mean) & $1-10$ & $\begin{array}{c}1.55 \\
(0.80)\end{array}$ & $\begin{array}{l}1.49 \\
(0.67)\end{array}$ & -0.06 & $\begin{array}{l}1.55 \\
(0.80)\end{array}$ \\
\hline Children in household (mean) & $0-7$ & $\begin{array}{l}1.06 \\
(1.19)\end{array}$ & $\begin{array}{c}0.67 \\
(1.08)\end{array}$ & $-0.39^{* * *}$ & $\begin{array}{l}1.06 \\
(1.19)\end{array}$ \\
\hline Close contacts outside household (mean) & $1-99$ & $\begin{array}{c}6.57 \\
(7.92)\end{array}$ & $\begin{array}{c}7.22 \\
(7.86)\end{array}$ & 0.65 & $\begin{array}{c}6.56 \\
(7.91)\end{array}$ \\
\hline Years of schooling (mean) & $7-21$ & $\begin{array}{l}11.40 \\
(2.18)\end{array}$ & $\begin{array}{l}11.14 \\
(2.37)\end{array}$ & $-0.25^{*}$ & $\begin{array}{l}11.39 \\
(2.18)\end{array}$ \\
\hline Months in unemployment (mean) & $0-428$ & $\begin{array}{c}38.24 \\
(45.05)\end{array}$ & $\begin{array}{c}54.93 \\
(50.60)\end{array}$ & $16.68^{* * *}$ & $\begin{array}{c}38.21 \\
(45.03)\end{array}$ \\
\hline Gender: male (share) & $\%$ & 38.8 & 45.5 & $6.7^{* *}$ & 38.8 \\
\hline Marital status: single (share) & $\%$ & 42.7 & 36.8 & $5.9^{*}$ & 42.7 \\
\hline Marital status: married (share) & $\%$ & 28.5 & 27.7 & 0.7 & 28.5 \\
\hline Marital status: divorced (share) & $\%$ & 26.9 & 32.8 & $5.9^{* *}$ & 26.9 \\
\hline Marital status: widowed (share) & $\%$ & 1.5 & 2.4 & 0.8 & 1.5 \\
\hline Immigrant $\left(1^{\text {st }}-3^{\text {rd }}\right.$ generation $)$ (share) & $\%$ & 30.0 & 26.0 & -4.0 & 30.0 \\
\hline Region: West-Germany (share) & $\%$ & 60.4 & 62.0 & 1.6 & 60.3 \\
\hline \multicolumn{6}{|l|}{ Health status } \\
\hline Disability: Officially registered & $\%$ & 6.5 & 16.7 & $4.3^{* * *}$ & 6.5 \\
\hline Disability: Currently applying for registration & $\%$ & 2.7 & 5.0 & $2.3^{*}$ & 2.7 \\
\hline Hospital stay (12 months) & $\%$ & 13.5 & 19.9 & $6.4^{* *}$ & 13.5 \\
\hline Number of doctoral consultations (3 months) & $0-90$ & $\begin{array}{c}2.66 \\
(4.90)\end{array}$ & $\begin{array}{c}3.55 \\
(6.07)\end{array}$ & $0.89^{* * *}$ & $\begin{array}{c}2.66 \\
(4.90)\end{array}$ \\
\hline
\end{tabular}

Source: PASS 2007-2014.

Note: All variables relate to pre-treatment PASS interviews; *denotes significance at the $10 \%$ level, ${ }^{* *}$ at the $5 \%$ level and ${ }^{* * *}$ at the $1 \%$ level. 
Table A2: Summary Statistics Test I.2

\begin{tabular}{|c|c|c|c|c|c|}
\hline & Scale & Treatment & Control & Difference & $\begin{array}{c}\text { Control } \\
\text { (Entropy } \\
\text { Balanced) } \\
\end{array}$ \\
\hline Number of observations: & & $\begin{array}{c}\mathrm{N}=180 \\
\text { mean / share } \\
(\text { std. dev. })\end{array}$ & $\begin{array}{c}\mathrm{N}=896 \\
\text { mean / share } \\
(\text { std. dev. })\end{array}$ & $\begin{array}{l}\text { Control - } \\
\text { Treatment }\end{array}$ & $\begin{array}{c}\mathrm{N}=896 \\
\text { mean / share } \\
\text { (std. dev.) }\end{array}$ \\
\hline \multicolumn{6}{|l|}{ Life satisfaction } \\
\hline Life satisfaction (mean) & $0-10$ & $\begin{array}{c}6.21 \\
(2.04)\end{array}$ & $\begin{array}{c}6.64 \\
(1.73)\end{array}$ & $0.42^{* * *}$ & $\begin{array}{c}6.71 \\
(1.71)\end{array}$ \\
\hline \multicolumn{6}{|l|}{ Income and Wealth } \\
\hline Equivalence income $^{1}$ (OECD scale) (mean) & $€$ & $\begin{array}{c}844.53 \\
(710.96)\end{array}$ & $\begin{array}{c}840.36 \\
(219.46)\end{array}$ & -4.17 &. \\
\hline Savings $<1000 €($ share $)$ & $\%$ & 87.8 & 83.7 & -4.1 & 87.8 \\
\hline Savings $<5000 €($ share $)$ & $\%$ & 10.6 & 12.3 & 1.7 & 10.6 \\
\hline Savings $>5000 €($ share $)$ & $\%$ & 1.7 & 3.7 & 2.0 & 1.7 \\
\hline \multicolumn{6}{|l|}{ Socio-demographic characteristics } \\
\hline Age (mean) & $18-63$ & $\begin{array}{c}41.99 \\
(11.04)\end{array}$ & $\begin{array}{l}42.94 \\
(9.98)\end{array}$ & 0.94 & $\begin{array}{c}41.99 \\
(10.58)\end{array}$ \\
\hline Adults in household (mean) & $1-10$ & $\begin{array}{c}1.89 \\
(1.15)\end{array}$ & $\begin{array}{c}1.63 \\
(0.73)\end{array}$ & $-0.26^{* * *}$ & $\begin{array}{c}1.89 \\
(1.31)\end{array}$ \\
\hline Children in household (mean) & $0-7$ & $\begin{array}{c}1.16 \\
(1.34)\end{array}$ & $\begin{array}{c}1.09 \\
(1.09)\end{array}$ & -0.07 & $\begin{array}{c}1.16 \\
(1.17)\end{array}$ \\
\hline Close contacts outside household (mean) & $1-99$ & $\begin{array}{c}7.72 \\
(8.06)\end{array}$ & $\begin{array}{c}7.20 \\
(7.61)\end{array}$ & -0.52 & $\begin{array}{c}7.72 \\
(8.29)\end{array}$ \\
\hline Years of schooling (mean) & $7-21$ & $\begin{array}{l}11.16 \\
(2.09)\end{array}$ & $\begin{array}{l}11.55 \\
(2.30)\end{array}$ & $0.38^{* *}$ & $\begin{array}{l}11.16 \\
(2.14)\end{array}$ \\
\hline Gender: male (share) & $\%$ & 43.3 & 33.0 & $-10.3^{* * *}$ & 43.3 \\
\hline Marital status: single (share) & $\%$ & 28.3 & 29.4 & 1.0 & 28.3 \\
\hline Marital status: married (share) & $\%$ & 37.8 & 38.5 & 0.7 & 37.8 \\
\hline Marital status: divorced (share) & $\%$ & 31.7 & 30.9 & -0.8 & 31.7 \\
\hline Marital status: widowed (share) & $\%$ & 2.2 & 0.9 & -1.3 & 2.2 \\
\hline Immigrant $\left(1^{\text {st }}-3^{\text {rd }}\right.$ generation $)$ (share $)$ & $\%$ & 27.2 & 27.8 & 0.6 & 27.2 \\
\hline Region: West-Germany (share) & $\%$ & 53.3 & 59.8 & 6.5 & 53.3 \\
\hline \multicolumn{6}{|l|}{ Health status } \\
\hline Disability: Officially registered & $\%$ & 7.2 & 6.1 & -1.1 & 7.2 \\
\hline Disability: Currently applying for registration & $\%$ & 2.8 & 1.7 & -1.1 & 2.8 \\
\hline Hospital stay (12 months) & $\%$ & 12.8 & 11.7 & -1.1 & 12.8 \\
\hline Number of doctoral consultations ( 3 months) & $0-90$ & $\begin{array}{c}3.04 \\
(4.68)\end{array}$ & $\begin{array}{c}2.35 \\
(4.43)\end{array}$ & $-0.64^{*}$ & $\begin{array}{c}3.04 \\
(8.74)\end{array}$ \\
\hline \multicolumn{6}{|l|}{ Job characteristics } \\
\hline Months in current employment spell (mean) & $0-499$ & $\begin{array}{c}29.32 \\
(60.66)\end{array}$ & $\begin{array}{c}57.09 \\
(76.08) \\
\end{array}$ & $27.76^{* * *}$ & $\begin{array}{c}29.33 \\
(38.07) \\
\end{array}$ \\
\hline
\end{tabular}

Source: PASS 2007-2014.

Note: All variables relate to pre-treatment PASS interviews; "denotes significance at the $10 \%$ level, ${ }^{* *}$ at the $5 \%$ level and ${ }^{* * *}$ at the $1 \%$ level. ${ }^{*}$ Variable skipped due to non-convergence of EB algorithm on the second moment. 
Table A3: Summary Statistics Test II.1

\begin{tabular}{|c|c|c|c|c|c|}
\hline & Scale & Treatment & Control & Difference & $\begin{array}{c}\text { Control } \\
\text { (Entropy } \\
\text { Balanced) }\end{array}$ \\
\hline Number of observations: & & $\begin{array}{c}\mathrm{N}=224 \\
\text { mean / share } \\
\text { (std. dev.) }\end{array}$ & $\begin{array}{c}\mathrm{N}=13,756 \\
\text { mean / } \\
\text { share } \\
\text { (std. dev.) }\end{array}$ & $\begin{array}{l}\text { Control - } \\
\text { Treatment }\end{array}$ & $\begin{array}{c}\mathrm{N}=13,756 \\
\text { mean / share } \\
\text { (std. dev.) }\end{array}$ \\
\hline \multicolumn{6}{|l|}{ Life satisfaction } \\
\hline Life satisfaction (mean) & $0-10$ & $\begin{array}{c}6.91 \\
(1.71)\end{array}$ & $\begin{array}{c}7.41 \\
(1.45)\end{array}$ & $0.50^{* * *}$ & $\begin{array}{c}6.94 \\
(1.70)\end{array}$ \\
\hline \multicolumn{6}{|l|}{ Income and Wealth } \\
\hline Monthly gross earnings (mean) & $€$ & $\begin{array}{l}1,248.13 \\
(653.40)\end{array}$ & $\begin{array}{c}2,479.30 \\
(1,924.71)\end{array}$ & $1,231.17^{* * *}$ & $\begin{array}{l}1246.41 \\
(652.99)\end{array}$ \\
\hline Equivalence income (OECD scale) (mean) & $€$ & $\begin{array}{c}966.64 \\
(368.90)\end{array}$ & $\begin{array}{c}1666.11 \\
(1526.56)\end{array}$ & $699.47^{* * *}$ & $\begin{array}{c}965.31 \\
(369.09)\end{array}$ \\
\hline Savings $<1000 €($ share $)$ & $\%$ & 75.4 & 31.2 & $-44.2^{* * *}$ & 75.3 \\
\hline Savings $<5000 €($ share $)$ & $\%$ & 18.3 & 22.8 & 4.5 & 18.3 \\
\hline Savings $>5000 €($ share $)$ & $\%$ & 5.4 & 43.2 & $37.9^{* * *}$ & 5.4 \\
\hline \multicolumn{6}{|l|}{ Socio-demographic characteristics } \\
\hline Age (mean) & $18-64$ & $\begin{array}{c}41.08 \\
(10.42)\end{array}$ & $\begin{array}{c}43.30 \\
(10.26)\end{array}$ & $2.22^{* * *}$ & $\begin{array}{c}41.02 \\
(10.41)\end{array}$ \\
\hline Adults in household (mean) & $1-10$ & $\begin{array}{c}1.70 \\
(0.77)\end{array}$ & $\begin{array}{c}1.83 \\
(0.67)\end{array}$ & $0.13^{* *}$ & $\begin{array}{c}1.69 \\
(0.77)\end{array}$ \\
\hline Children in household (mean) & $0-8$ & $\begin{array}{c}0.97 \\
(1.05)\end{array}$ & $\begin{array}{c}0.87 \\
(1.01)\end{array}$ & -0.11 & $\begin{array}{c}0.97 \\
(1.05)\end{array}$ \\
\hline Close contacts outside household (mean) & $1-99$ & $\begin{array}{c}8.70 \\
(10.30)\end{array}$ & $\begin{array}{c}7.93 \\
(7.49)\end{array}$ & -0.78 & $\begin{array}{c}8.69 \\
(10.29)\end{array}$ \\
\hline Years of schooling (mean) & $7-21$ & $\begin{array}{l}11.44 \\
(2.03)\end{array}$ & $\begin{array}{l}12.73 \\
(2.70)\end{array}$ & $1.30^{* * *}$ & $\begin{array}{l}11.42 \\
(2.03)\end{array}$ \\
\hline Gender: male (share) & $\%$ & 41.5 & 50.3 & $8.8^{* * *}$ & 41.5 \\
\hline Marital status: single (share) & $\%$ & 30.8 & 29.5 & -1.3 & 30.8 \\
\hline Marital status: married (share) & $\%$ & 32.1 & 53.4 & $21.2^{* * *}$ & 32.1 \\
\hline Marital status: divorced (share) & $\%$ & 33.5 & 15.0 & $18.5^{* * *}$ & 33.5 \\
\hline Marital status: widowed (share) & $\%$ & 3.1 & 1.7 & -1.4 & 3.1 \\
\hline Immigrant $\left(1^{\text {st }}-3^{\text {rd }}\right.$ generation $)$ (share) & $\%$ & 24.6 & 18.7 & $-5.8^{* *}$ & 24.5 \\
\hline Region: West-Germany (share) & $\%$ & 54.5 & 72.0 & $17.6^{* * *}$ & 54.4 \\
\hline \multicolumn{6}{|l|}{ Health status } \\
\hline Disability: Officially registered & $\%$ & 5.8 & 7.2 & 1.4 & 5.8 \\
\hline Disability: Currently applying for registration & $\%$ & 1.3 & 1.3 & -0.0 & 1.3 \\
\hline Hospital stay (12 months) & $\%$ & 9.4 & 10.4 & 1.0 & 9.4 \\
\hline Number of doctoral consultations ( 3 months) & $0-70$ & $\begin{array}{c}1.82 \\
(2.50)\end{array}$ & $\begin{array}{c}2.09 \\
(3.48)\end{array}$ & 0.27 & $\begin{array}{c}1.82 \\
(2.50)\end{array}$ \\
\hline \multicolumn{6}{|l|}{ Job characteristics } \\
\hline Work strain (mean) & $1-10$ & $\begin{array}{c}6.63 \\
(2.45)\end{array}$ & $\begin{array}{c}5.54 \\
(2.80)\end{array}$ & $-1.09^{* * *}$ & $\begin{array}{c}6.62 \\
(2.44)\end{array}$ \\
\hline Hours (per week) & $15-80$ & $\begin{array}{c}36.06 \\
(10.90)\end{array}$ & $\begin{array}{c}40.31 \\
(10.77)\end{array}$ & $4.25^{* * *}$ & $\begin{array}{c}36.01 \\
(10.89)\end{array}$ \\
\hline Months in current employment spell (mean) & $0-647$ & $\begin{array}{c}51.94 \\
(77.67)\end{array}$ & $\begin{array}{c}98.97 \\
(106.57)\end{array}$ & $47.03^{* * *}$ & $\begin{array}{c}51.87 \\
(77.62)\end{array}$ \\
\hline Employment Type: Blue collar-worker (share) & $\%$ & 33.0 & 23.0 & $-10.0^{* * *}$ & 33.0 \\
\hline Employment Type: White collar-worker (share) & $\%$ & 57.6 & 68.2 & $10.8^{* * *}$ & 57.5 \\
\hline Employment Type: Self-employed (share) & $\%$ & 9.4 & 8.7 & -0.7 & 9.4 \\
\hline
\end{tabular}

Source: PASS 2007-2014.

Note: All variables relate to pre-treatment PASS interviews; *denotes significance at the $10 \%$ level, ${ }^{* *}$ at the $5 \%$ level and ${ }^{* * *}$ at the $1 \%$ level. 
Table A4: Summary Statistics Test II.2

\begin{tabular}{|c|c|c|c|c|c|}
\hline & Scale & Treatment & Control & Difference & $\begin{array}{l}\text { Control } \\
\text { (Entropy } \\
\text { Balanced) }\end{array}$ \\
\hline Number of observations: & & $\begin{array}{c}\mathrm{N}=410 \\
\text { mean / share } \\
(\text { std. dev. })\end{array}$ & $\begin{array}{c}\mathrm{N}=806 \\
\text { mean / share } \\
(\text { std. dev. })\end{array}$ & $\begin{array}{l}\text { Control- } \\
\text { Treatment }\end{array}$ & $\begin{array}{c}\mathrm{N}=806 \\
\text { mean / share } \\
\text { (std. dev.) }\end{array}$ \\
\hline \multicolumn{6}{|l|}{ Life satisfaction } \\
\hline Life satisfaction (mean) & $0-10$ & $\begin{array}{c}6.71 \\
(1.79)\end{array}$ & $\begin{array}{c}6.64 \\
(1.71)\end{array}$ & -0.07 & $\begin{array}{c}6.70 \\
(1.63)\end{array}$ \\
\hline \multicolumn{6}{|l|}{ Income and Wealth } \\
\hline Monthly gross earnings (mean) & $€$ & $\begin{array}{l}1143.09 \\
(528.93)\end{array}$ & $\begin{array}{c}953.51 \\
(474.78)\end{array}$ & $-189.57^{* * *}$ & $\begin{array}{l}1142.68 \\
(528.84)\end{array}$ \\
\hline Equivalence income (OECD scale) (mean) & $€$ & $\begin{array}{c}877.92 \\
(238.88)\end{array}$ & $\begin{array}{c}838.84 \\
(207.84)\end{array}$ & $-39.08^{* * *}$ & $\begin{array}{c}877.61 \\
(238.84)\end{array}$ \\
\hline Savings $<1000 €($ share $)$ & $\%$ & 78.3 & 83.9 & $5.6^{* *}$ & 78.3 \\
\hline Savings $<5000 €($ share $)$ & $\%$ & 16.3 & 12.4 & $-3.9^{*}$ & 16.3 \\
\hline Savings $>5000 €($ share $)$ & $\%$ & 4.6 & 3.5 & -1.2 & 4.6 \\
\hline \multicolumn{6}{|l|}{ Socio-demographic characteristics } \\
\hline Age (mean) & $19-63$ & $\begin{array}{c}40.36 \\
(10.28)\end{array}$ & $\begin{array}{l}42.70 \\
(9.92)\end{array}$ & $2.33^{* * *}$ & $\begin{array}{c}40.35 \\
(10.27)\end{array}$ \\
\hline Adults in household (mean) & $1-10$ & $\begin{array}{c}1.69 \\
(0.71)\end{array}$ & $\begin{array}{c}1.62 \\
(0.74)\end{array}$ & -0.07 & $\begin{array}{l}1.69 \\
(0.71)\end{array}$ \\
\hline Children in household (mean) & $0-6$ & $\begin{array}{c}1.06 \\
(1.03)\end{array}$ & $\begin{array}{c}1.14 \\
(1.11)\end{array}$ & 0.09 & $\begin{array}{l}1.06 \\
(1.02)\end{array}$ \\
\hline Close contacts outside household (mean) & $1-99$ & $\begin{array}{c}7.26 \\
(6.19)\end{array}$ & $\begin{array}{c}7.28 \\
(7.86)\end{array}$ & 0.02 & $\begin{array}{c}7.26 \\
(6.19)\end{array}$ \\
\hline Years of schooling (mean) & $7-21$ & $\begin{array}{l}11.53 \\
(2.03)\end{array}$ & $\begin{array}{l}11.52 \\
(2.28)\end{array}$ & -0.01 & $\begin{array}{l}11.53 \\
(2.03)\end{array}$ \\
\hline Gender: male (share) & $\%$ & 37.6 & 31.5 & $-6.0^{* *}$ & 37.6 \\
\hline Marital status: single (share) & $\%$ & 32.4 & 29.7 & -2.8 & 32.4 \\
\hline Marital status: married (share) & $\%$ & 35.4 & 38.1 & 2.7 & 35.4 \\
\hline Marital status: divorced (share) & $\%$ & 30.2 & 31.0 & 0.8 & 30.2 \\
\hline Marital status: widowed (share) & $\%$ & 0.1 & 0.1 & 0.0 & 0.1 \\
\hline Immigrant $\left(1^{\text {st }}-3^{\text {rd }}\right.$ generation $)($ share $)$ & $\%$ & 22.2 & 28.3 & $6.1^{* *}$ & 22.2 \\
\hline Region: West-Germany (share) & $\%$ & 58.5 & 59.9 & 1.4 & 58.5 \\
\hline \multicolumn{6}{|l|}{ Health status } \\
\hline Disability: Officially registered & $\%$ & 6.1 & 5.5 & -0.6 & 6.1 \\
\hline Disability: Currently applying for registration & $\%$ & 2.7 & 1.9 & -0.8 & 2.7 \\
\hline Hospital stay (12 months) & $\%$ & 9.0 & 11.8 & & 9.0 \\
\hline Number of doctoral consultations ( 3 months) & $0-90$ & $\begin{array}{c}2.17 \\
(5.41)\end{array}$ & $\begin{array}{c}2.37 \\
(4.59)\end{array}$ & 0.20 & $\begin{array}{c}2.17 \\
(5.40)\end{array}$ \\
\hline \multicolumn{6}{|l|}{ Job characteristics } \\
\hline Work strain (mean) & $1-10$ & $\begin{array}{c}6.67 \\
(2.38)\end{array}$ & $\begin{array}{c}6.90 \\
(2.23)\end{array}$ & $0.23^{*}$ & $\begin{array}{c}6.66 \\
(2.38)\end{array}$ \\
\hline Hours (per week) & $15-80$ & $\begin{array}{c}34.26 \\
(11.09)\end{array}$ & $\begin{array}{c}32.34 \\
(11.74)\end{array}$ & $-1.92^{* * *}$ & $\begin{array}{c}34.25 \\
(11.09)\end{array}$ \\
\hline Months in current employment spell (mean) & $0-499$ & $\begin{array}{c}46.19 \\
(67.41)\end{array}$ & $\begin{array}{c}56.93 \\
(74.64)\end{array}$ & $10.75^{* *}$ & $\begin{array}{c}46.17 \\
(67.40)\end{array}$ \\
\hline Employment Type: Blue collar-worker (share) & $\%$ & 32.9 & 32.6 & -0.3 & 32.9 \\
\hline Employment Type: White collar-worker (share) & $\%$ & 57.3 & 55.5 & -1.9 & 57.3 \\
\hline Employment Type: Self-employed (share) & $\%$ & 9.5 & 11.7 & 2.2 & 9.5 \\
\hline
\end{tabular}

Source: PASS 2007-2014.

Note: All variables relate to pre-treatment PASS interviews; "denotes significance at the 10\% level, ${ }^{* *}$ at the $5 \%$ level and ${ }^{* * *}$ at the $1 \%$ level. 
Figure A1: Time trends in life satisfaction

Test I.1

Unemployment $\rightarrow$ Subsidized Employment

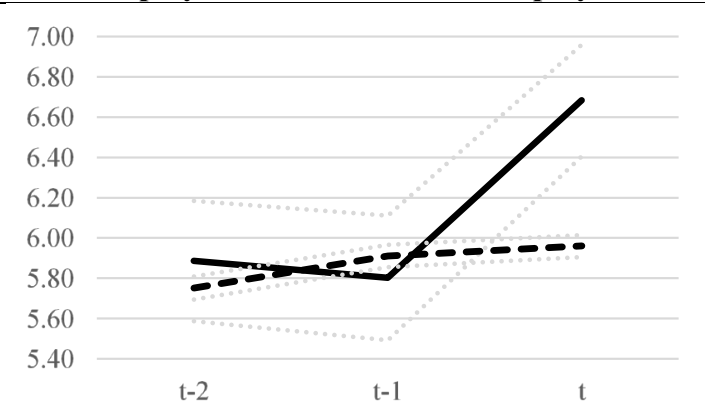

Test II.1

Regular employment $\rightarrow$ Subsidized employment

7.40

7.20

7.00

6.80

6.60

6.40

6.20

$\mathrm{t}-2$

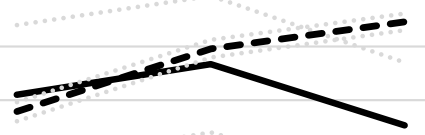

t
Test I.2

Subsidized Employment $\rightarrow$ Unemployment

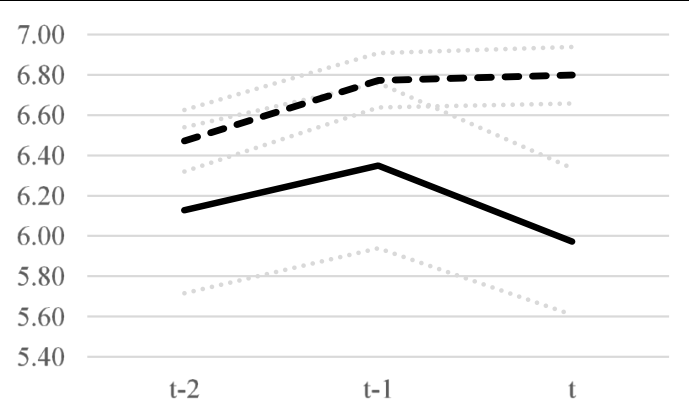

Test II.2

Subsidized employment $\rightarrow$ Regular employment

7.40

7.20

7.00

6.80

6.60

6.40

6.20

$\mathrm{t}-2$

$\mathrm{t}-1$

Source: PASS 2007-2014.

Note: Solid lines denote treatment group trends, dashed lines denote control group trends. Dotted lines represent $95 \%$ confidence intervals. At time t the treated individuals have recently changed labor market status whereas control group individuals remain in the initial status. All of the control groups are reweighted using EB. At time $t$-1, treated individuals are interviewed for the last time before switching. At time t-2, treated individuals are interviewed for the second-last time before switching. 


\section{Diskussionsbeiträge - Fachbereich Wirtschaftswissenschaft - Freie Universität Berlin Discussion Paper - School of Business and Economics - Freie Universität Berlin}

2016 erschienen:

2016/1 BARTELS, Charlotte und Maximilian STOCKHAUSEN

Children's opportunities in Germany - An application using multidimensional measures

Economics

2016/2 BÖNKE, Timm; Daniel KEMPTNER und Holger LÜTHEN

Effectiveness of early retirement disincentives: individual welfare, distributional and fiscal implications

\section{Economics}

2016/3 NEIDHÖFER, Guido

Intergenerational Mobility and the Rise and Fall of Inequality: Lessons from Latin America

Economics

2016/4 TIEFENSEE, Anita und Christian WESTERMEIER Intergenerational transfers and wealth in the Euro-area: The relevance of inheritances and gifts in absolute and relative terms

Economics

2016/5 BALDERMANN, Claudia; Nicola SALVATI und Timo SCHMID

Robust small area estimation under spatial non-stationarity

Economics

2016/6 GÖRLITZ, Katja und Marcus TAMM

Information, financial aid and training participation: Evidence from a

randomized field experiment

Economics

2016/7 JÄGER, Jannik und Theocharis GRIGORIADIS

Soft Budget Constraints, European Central Banking and the Financial Crisis

Economics

2016/8 SCHREIBER, Sven und Miriam BEBLO

Leisure and Housing Consumption after Retirement: New Evidence on the Life-Cycle Hypothesis

Economics

2016/9 SCHMID, Timo; Fabian BRUCKSCHEN; Nicola SALVATI und Till ZBIRANSKI Constructing socio-demographic indicators for National Statistical Institutes using mobile phone data: estimating literacy rates in Senegal

Economics 
2016/10 JESSEN, Robin; ROSTAM-AFSCHAR, Davud und Sebastian SCHMITZ How Important is Precautionary Labor Supply?

Economics

2016/11 BIER, Solveig; Martin GERSCH, Lauri WESSEL, Robert TOLKSDORF und Nina KNOLL

Elektronische Forschungsplattformen (EFP) für Verbundprojekte: Bedarfs-, Angebots- und Erfahrungsanalyse

Wirtschaftsinformatik

2016/12 WEIDENHAMMER, Beate; Timo SCHMID, Nicola SALVATI und Nikos TZAVIDIS

A Unit-level Quantile Nested Error Regression Model for Domain Prediction with Continuous and Discrete Outcomes

Economics

2016/13 TZAVIDIS, Nikos; Li-Chun ZHANG, Angela LUNA HERNANDEZ, Timo SCHMID, Natalia ROJAS-PERILLA

From start to finish: a framework for the production of small area official statistics

Economics

2016/14 GASTEIGER, Emanuel

Do Heterogeneous Expectations Constitute a Challenge for Policy Interaction? Economics 